\title{
Biodenitrification of Hanford Groundwater and Process Effluents: FY 1988 Status Report
}
S. S. Koegler
W. O. Heath
T. M. Brouns
R. J. Hicks

September 1989

Prepared for the U.S. Department of Energy under Contract DE-AC06-76RLO 1830

Pacific Northwest Laboratory Operated for the U.S. Department of Energy by Battelle Memorial Institute 


\title{
DISCLAIMER
}

This program was prepared as an account of work sponsored by an agency of the United States Government. Neither the United States Government nor any agency thereof, nor Battelle Memorial Institute, nor any or their em. ployees, makes any warranty, expressed or implied, or assumes any legal liability or responsibility for the accuracy, completeness, or usefulness of any information, apparatus, product, or process disclosed, or represents that its use would not infringe privately owned rights. Reference herein to any specific commercial product, process, or service by trade name, trademark, manufacturer, or otherwise, does not necessarily constitute or imply its en. dorsement, recommendation, or favoring by the United States Government of any agency thereof, or Battelle Memorial Institute. The views and opinions of authors expressed herein do not necessarily state or reflect those of the United States Government or any agency thereof.

\author{
PACIFIC NORTHWEST LABORATORY \\ operated by \\ BATTELLE MEMORIAL INSTITUTE \\ for the \\ UNITED STATES DEPARTMENT OF ENERGY \\ under Contract DE-ACO6-76RLO 1830
}

Printed in the United States of America

Available to DOE and DOE contractors trom the

Office of Scientific and Technical Information, P.O. Box 62, Oak Ridge, TN 37831:

prices available from (615) 576-8401. FTS 626-8401.

Available to the public from the National Technical Information Service,

U.S. Department of Commerce, 5285 Port Royal Rd., Springrield, VA 22161.

NTIS Price Codes, Microfiche A01

\begin{tabular}{cc}
\multicolumn{2}{c}{ Printed Copy } \\
& $\begin{array}{c}\text { Price } \\
\text { Pages }\end{array}$ \\
$\frac{\text { Codes }}{001-025}$ & A02 \\
$026-050$ & A03 \\
$051-075$ & A04 \\
$076-100$ & A05 \\
$101-125$ & A06 \\
$126-150$ & A07 \\
$151-175$ & A08 \\
$176-200$ & A09 \\
$201-225$ & A10 \\
$226-250$ & A11 \\
$251-275$ & A12 \\
$276-300$ & A13
\end{tabular}


S. S. Koegler

T. M. Brouns

W. 0 . Heath

R. J. Hicks

September 1989

Prepared for the U.S. Department of Energy under Contract DE-AC06-76RLO 1830

Pacific Northwest Laboratory Richland, Washington 99352 


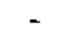




\section{SUMMARY}

Laboratory screening tests were performed to select microorganisms for their ability to destroy nitrates and carbon tetrachloride in Hanford groundwaters. The microorganisms were subsequently tested in bench-scale experiments to determine the fundamental kinetic constants for denitrification with acetate. The microorganisms were also used as the inoculum for the pilotscale bioreactor system, which was designed, constructed, and operated in FY 1988. The bench-scale denitrification kinetic data were analyzed using two rate models. The best fit was obtained using a first-order expression. The kinetic constants determined in the bench-scale experiments were later used to set operating parameters for the pilot-scale bioreactor test. -The pilot-scale bioreactor system consisted of a 50-L continuous-stirred tank bioreactor, a 280-L clarifier, associated feed components, and a data acquisition and control system. The pilot plant was designed as a module for ease of installation and to facilitate relocation for on-site demonstration testing. The pilot-scale bioreactor was installed and operated in FY 1988, but steady-state operating data are not yet available. Preliminary denitrification data show destruction of nitrate to concentrations less than drinking water standards. A preliminary engineering evaluation was also completed in Fy 1988 that examined the engineering feasibility of biodenitrification for the $\mathrm{UO}_{3} \mathrm{Plant}$ process condensate through microorganism laboratory testing, development of flowsheets, and equipment size and cost estimates. 



\section{ACKNOWLEDGMENTS}

We would like to thank Dr. H. David Stensel from the University of Washington's Department of Civil Engineering for his support in this project. Dr. Stensel was responsible for the bench-scale kinetics tests that were conducted to determine denitrification reaction rates with the Hanford groundwater consortium. 


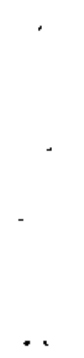

. 


\section{CONTENTS}

SUMMARY .......................... $\mathbf{i} \mathbf{i}$

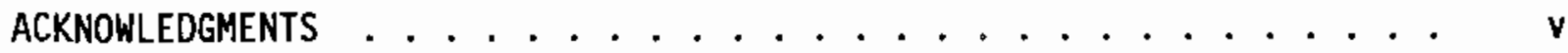

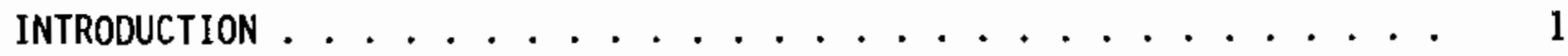

RESULTS AND CONCLUSIONS ................. 3

DESCRIPTION OF BIODENITRIFICATION ............. 5

MATHEMATICAL MODEL ...................... 6

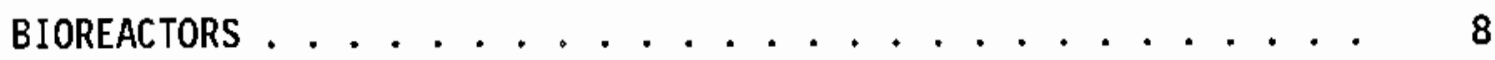

MICROORGANISM TESTS .......................... 11

OBJECTIVES OF MICROORGANISM TESTS .............. 11

MICROORGANISM TEST RESULTS . . . . . . . . . . . . 11

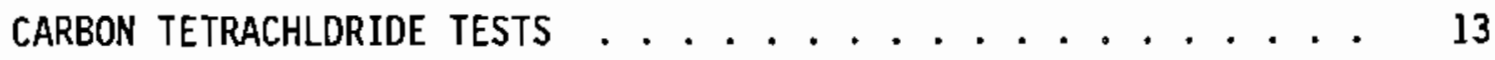

CARBON TETRACHLORIDE TEST CONCLUSIONS ........... 15

BENCH-SCALE KINETIC TESTS . . . . . . . . . . . . 17

OBJECTIVES OF KINETIC TESTS . . . . . . . . . . . 17

DESCRIPTION OF KINETIC TESTS . . . . . . . . . . 17

RESULTS OF KINETIC TESTS ................ 18

PILOT-SCALE BIOREACTOR TESTS . . . . . . . . . . . . . 23

OBJECTIVES OF PILOT-SCALE TESTS .............. 23

Task 1, Bioreactor and Pilot-Plant Design ....... 23

Task 2, Pilot-Plant Fabrication and Installation ..... 24

Task 3, Pilot-Plant Testing .......... . 26

DESCRIPTION OF PILOT-SCALE EQUIPMENT ............ 26

Feed Tanks.................... 28

Bioreactor ................. 29 


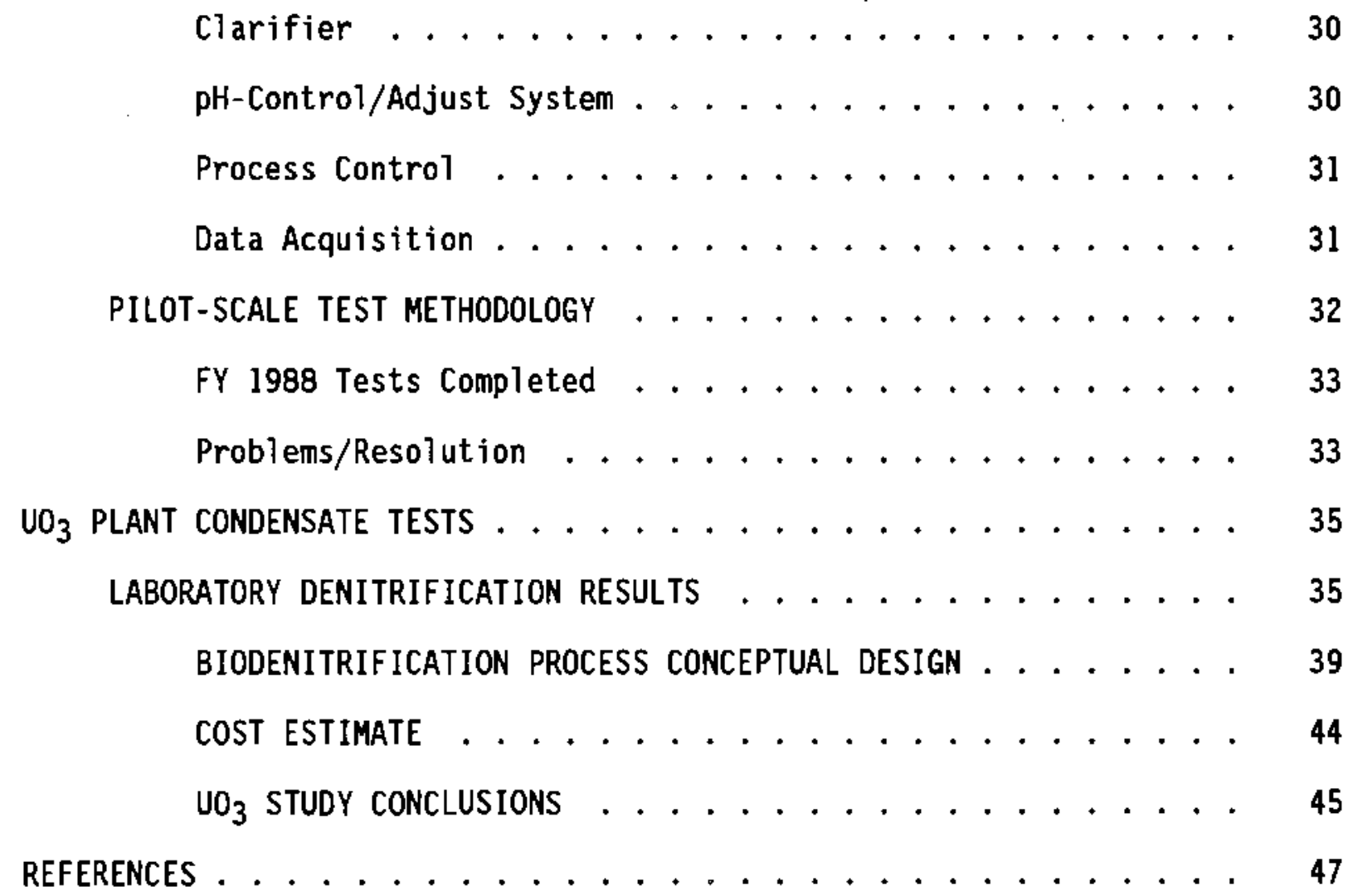




\section{FIGURES}

1 Suspended Growth Bioreactor ................. 8

2 Fluidized Bed Bioreactor ............... 9

3 Denitrification in a Simulated Waste Stream Inoculated with

Denitrifying Culture Obtained from Hanford Groundwaters . . . . . 12

4 Flow Diagram of Method Used for Monitoring ${ }^{14} \mathrm{CO}_{2}$ in Samples... 14

$5 \mathrm{CCl}_{4}$ Degradation in Samples Incubated with Hanford Denitrifying Cuttures .................. 15

6 Substrate Removal Efficiency as a Function of Biomass Concentration and Residence Time ........... 19

7 Substrate Yield as a Function of Residence Time . . . . . . 20

8 Flow Diagram of Biodenitrification Pilot-Plant ........ 24

9 Bioreactor and Process Control Instrumentation ........ 27

10 Bioreactor Feed Tanks . . . . . . . . . . . . 28

11 Clarifier........................ 29

12 Test 1: Laboratory Denitrification Rate in Moles of Nitrogen Produced per Hour from a 10-mL Sample .......... 36

13 Test 2: Laboratory Denitrification Rates in Moles of Nitrate Destroyed per Hour from a $10-\mathrm{mL}$ Sample .......... 38

14 Test 2: Percent Nitrate Destroyed per Hour . . . . . . . . 39

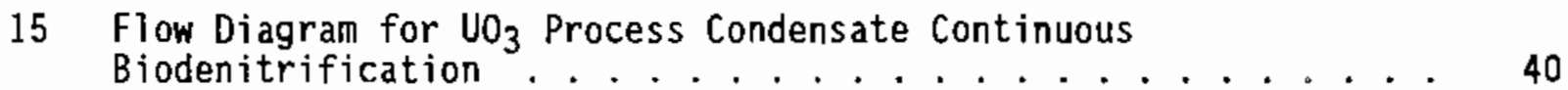

16 Flow Diagram for $\mathrm{UO}_{3}$ Process Condensate Batch Biodenitrification .............. 40 


\section{$\underline{\text { TABLES }}$}

1 Cultures Tested for Denitrification . . . . . . . . . 12

2 Environmental Parameters Influencing Biodenitrification . . . . . 13

3 Steady-State Operating Conditions . . . . . . . . . . . 18

4 Calculated Kinetic Constants . . . . . . . . . . . 2l

5 Biodenitrification Pilot-Plant Flowsheet . . . . . . . . 25

6 Biological Denitrification of Process Condensate for a $10-\mathrm{mL}$ Sample Diluted 10:1 with Water . . . . . . . . . . . 37

7 Flowsheet for $\mathrm{UO}_{3}$ Process Condensate Continuous Biodenitrification ................. . . 42

8 Flowsheet for $\mathrm{UO}_{3}$ Process Condensate Batch

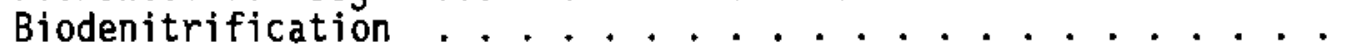




\section{INTRODUCTION}

This report summarizes the results of biodenitrification studies performed at the laboratory, bench, and pilot scales by the Pacific Northwest Laboratory $(P N L){ }^{(a)}$ in FY 1988 . The studies were conducted under the Environmental Restoration Remedial Actions Program and the Northwest Hazardous waste RDDT\&E Center. The purpose of the biodenitrification program is to determine the applicability of biological denitrification and organic contaminant destruction to groundwaters and process effluents. This technology will be transferred to the Hanford operating contractor and to other U.S. Department of Energy (DOE) facilities.

Liquid wastes have been generated by 40 years of Hanford Site operations. Previously, some of these wastes, which contain radioactive, hazardous, and regulated chemicals (including nitrates and organics) have been discharged to the soil column. Current DOE policy prohibits the disposal of contaminated liquids directly to the environment. Biodenitrification using facultative anaerobic microorganisms is one promising technology for nitrate removal from the contaminated aqueous streams.

(a) The Pacific Northwest Laboratory is operated by Battelle Memorial Institute for the U.S. Department of Energy under Contract DE-ACO6-76 RLO 1830. 


\section{RESULTS AND CONCLUSIONS}

The biodenitrification project was successful in developing and testing microorganisms and processes for treating nitrates in Hanford groundwater and the $\mathrm{U0}_{3} \mathrm{Plant}$ process condensate. The following are specific project accomplishments for FY 1988:

- Microorganisms selected from a variety of soils and sludges were tested for their capacity to destroy nitrates. The more effective microorganisms were further tested for their ability to degrade $\mathrm{CCl}_{4}$ under denitrifying conditions. Carbon tetrachloride destruction was confirmed by radio-7abeled $\mathrm{CCl}_{4}$ tests. A culture of these microorganisms was used as the inoculum for the bench-scale kinetic tests and for subsequent pilot-scale demonstration tests.

- Bench-scale tests run with a series of 5-L continuous flow bioreactors determined the kinetic constants for nitrate destruction using acetate as the carbon source (substrate). The rate constants $k$ and $K_{d}$ were calculated, together with the biomass and nitrate yields. These constants were used to determine pilot plant operating parameters, including the feed rate and the optimum acetate/nitrate feed ratio.

- A 50-L continuous-flow, stirred-tank bioreactor system was designed and constructed. The bioreactor was operated with simulated U1/U2 crib groundwater feed and demonstrated denitrification at a feed rate of $-2 \mathrm{~L} / \mathrm{h}$. The bioreactor is suitable for obtaining engineering and process information to determine the relevance of bioremediation to specific Hanford applications. The unit is skid-mounted for easy transport to a remote site for future on-site demonstrations.

- A laboratory and technical study to determine the feasibility of biological denitrification of $\mathrm{UO}_{3} \mathrm{Pl}$ ant process effluents indicated that biodenitrification is a viable option. Flowsheets and equipment estimates were prepared from the laboratory microorganism feasibility test results.

The biological tests completed at the bench and pilot scales demonstrated the denitrification of simulated U1/U2 groundwater. Further tests will be completed in $\mathrm{FY} 1989$, also with simulants, to confirm $\mathrm{CC}_{4}$ degradation at the pilot scale. Tests with actual U1/U2 groundwater, either on site or at the 324 Building, will be required to confirm operating characteristics. The pilot-scale bioreactor equipment is suitable for either lownitrate groundwater or high-nitrate process effluent testing. The bioreactor 
can be used for additional tests in FY 1989 and FY 1990 in its present location at the 324 Building, or at a remote location. 


\section{DESCRIPTION OF BIODENITRIFICATION}

Biological denitrification is defined as the dissimilatory reduction of nitrate $\left(\mathrm{NO}_{3}^{-}\right)$to gaseous dinitrogen $\left(\mathrm{N}_{2}\right)$ and/or nitrous oxide $\left(\mathrm{N}_{2} \mathrm{O}\right)$ by facultative anaerobic microorganisms. Prokaryotes (bacteria) are the only organisms that have the physiological property of denitrification; this property is widely distributed among the various groups of bacteria. Denitrifying bacteria are basically aerobes and prefer to use oxygen as their terminal electron acceptor. However, in the absence of oxygen, these bacteria possess the capacity to use nitrate as the terminal electron acceptor in an electron transport chain.

Numerous environmental factors are known to affect biodenitrification. of particular importance is oxygen. Generaliy, denitrification is repressed in the presence of oxygen. However, denitrification has been observed at oxygen concentrations approaching 5\% (Knowles 1982). The level of oxygen that can be tolerated appears to be dependent upon the taxonomic group involved in the process. Other factors include, but are not 1 imited to, temperature, $\mathrm{pH}$, the carbon/nitrogen $(\mathrm{C} / \mathrm{N})$ mole ratio, the need for cofactors such as phosphorus, or the presence of inhibitors such as heavy metals.

The overall general equation for biological denitrification as described by McCarty et al. (1969) is:

$$
\mathrm{NO}_{3}^{-}+\text {carbon source } \cdots \mathrm{N}_{2}+\mathrm{CO}_{2}+\mathrm{H}_{2} \mathrm{O}+\mathrm{OH}^{-}+\text {biomass }
$$

For each nitrate ion converted, a hydroxyl ion is produced. The hydroxyl ion generation causes the $\mathrm{pH}$ to increase in the bioreactor as denitrification proceeds and may require neutralization to maintain the environment in the bioreactor within pH limits of 6.5 to 8.5. Walker et al. (1981) give the approximate chemical composition of biomass as $\mathrm{C}_{5} \mathrm{H}_{7} \mathrm{O}_{2} \mathrm{~N}$. Measurements indicated that 0.065 moles of biomass $\left(\mathrm{C}_{5} \mathrm{H}_{7} \mathrm{O}_{2} \mathrm{~N}\right), 0.76$ moles of $\mathrm{CO}_{2}$, and 0.47 moles of $\mathrm{N}_{2}$ were produced, and 1.08 moles of methanol or 0.54 moles of ethanol were consumed for each mole of nitrate converted. The biodenitrification reaction is also exothermic with a heat of reaction of $-138.36 \mathrm{kca} 1$ 
per mole of methanol (Knowles 1982). The temperature increase caused by the reaction may need to be considered in the design and operation of a bioreactor.

\section{MATHEMATICAL MODEL}

Mathematical models of biological systems are used for the scale-up of laboratory or bench-scale processes. Microbial growth and metabolism have traditionally been modelled using the Monod expression which relates cell or biomass growth rate to substrate and biomass concentrations (Monod 1949). The model's simplicity and ease of application have resulted in its extensive use in both fermentation and wastewater treatment systems to describe substrate utilization and microbial growth. The rate expression for substrate utilization is:

$$
-d S / d t=(k S x) /\left(K_{S}+S\right)
$$

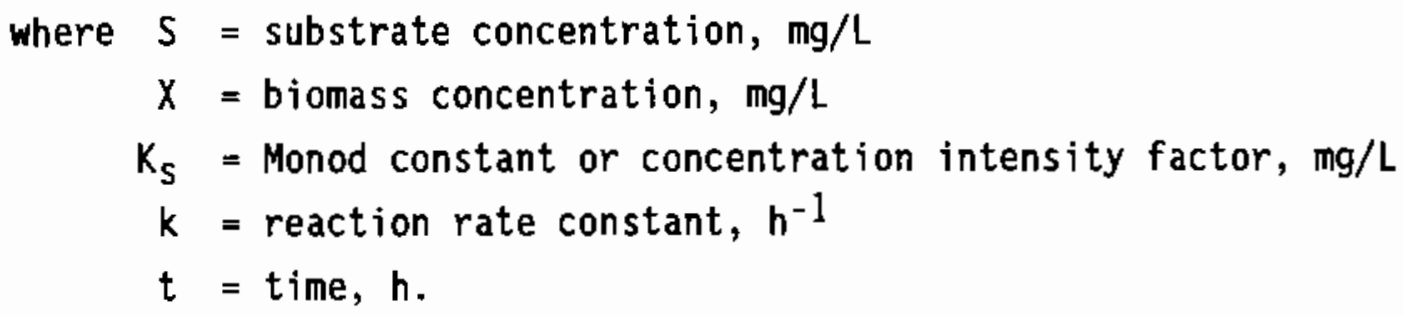

Studies of denitrifying bacteria have found that nitrate does not limit bacterial growth and metabolism until concentrations drop below regulated nitrate discharge levels (Sundstrom et al. 1979). Therefore, the carbon source becomes the limiting substrate for kinetic considerations. The growth rate is simply the rate of substrate utilization multiplied by a biomass yield coefficient. The rate of change of biomass concentration also includes a biomass decay term to account for cell death. The overall biomass growth rate expression is:

$$
d X / d t=Y(-d S / d t)-K_{d} X=Y(k S X) /\left(K_{S}+S\right)-K_{d} X
$$


where $Y=$ biomass yield coefficient (dimensionless)

$K_{d}=$ biomass decay constant, $h^{-1}$.

Other kinetic expressions have also been used successfully to describe microbial growth in wastewater systems. Zero-, first-, and second-order models are frequently used (Sundstrom et al. 1979, Benefield et al. 1980). The first-order model shown below, although simpler than the Monod expression, has been used to model substrate utilization.

$$
-d S / d t=k S X
$$

As with the Monod equation, a biomass growth rate expression includes yield and decay terms.

$$
d X / d t=Y(k S X)-K_{d} X
$$

Rate constants, yie1d coefficients, and decay constants are determined from batch and continuous growth data. Several models are used when analyzing the data to determine which expression best describes the microbial growth and metabolism. Substrate and biomass rate expressions are then used in overall material balances to design larger bioreactors for nitrate treatment systems. Reaction rates must be confirmed at each stage of development to ensure that the final treatment process will operate effectively. Residence time and reactor volume are regulated by the kinetics of the denitrifying bacteria and the composition of the process stream requiring treatment.

A solids residence time is also important in biological systems and is controlled in most processes by the recycle rate, settling characteristics of the biomass, and sludge wastage rate. The minimum solids residence time, or sludge age, required is calculated from growth kinetics but can be used as a process variable to control discharge concentrations. The ratio of carbon to nitrogen $(C / N)$ in the bioreactor is a particularly important parameter for denitrification system design. Large $\mathrm{C} / \mathrm{N}$ ratios will result in the discharge of effluent from the bioreactor containing very little nitrate, but the biological oxygen demand (BOD) may exceed acceptable limits due to excess 
carbon. If low $\mathrm{C} / \mathrm{N}$ ratios are maintained, low nitrate discharge levels may be difficult to attain. Optimum sludge age, temperature, $\mathrm{pH}$, and $\mathrm{C} / \mathrm{N}$ ratio must be determined from kinetic studies using laboratory or bench-scale continuous bioreactors.

\section{BIOREACTORS}

Several types of chemical reactors can be used to denitrify nitratecontaining waste waters. Sutton (1987) describes the two classes of bioreactors used for all industrial biological treatment as suspended-growth reactors, in which the biomass is suspended as free organisms, and fixed-film reactors, in which the organisms grow on a solid medium.

The suspended-growth reactor is usually a batch or continuous-stirred tank reactor. To achieve effective denitrification rates in a continuousstirred tank reactor, some means of concentrating or recycling the biomass is necessary. A continuous-suspended growth reactor is shown in Figure 1.

In the fixed-film bioreactor, a biofilm develops at the surface of the packing media which serves to concentrate the bacteria or biomass higher than

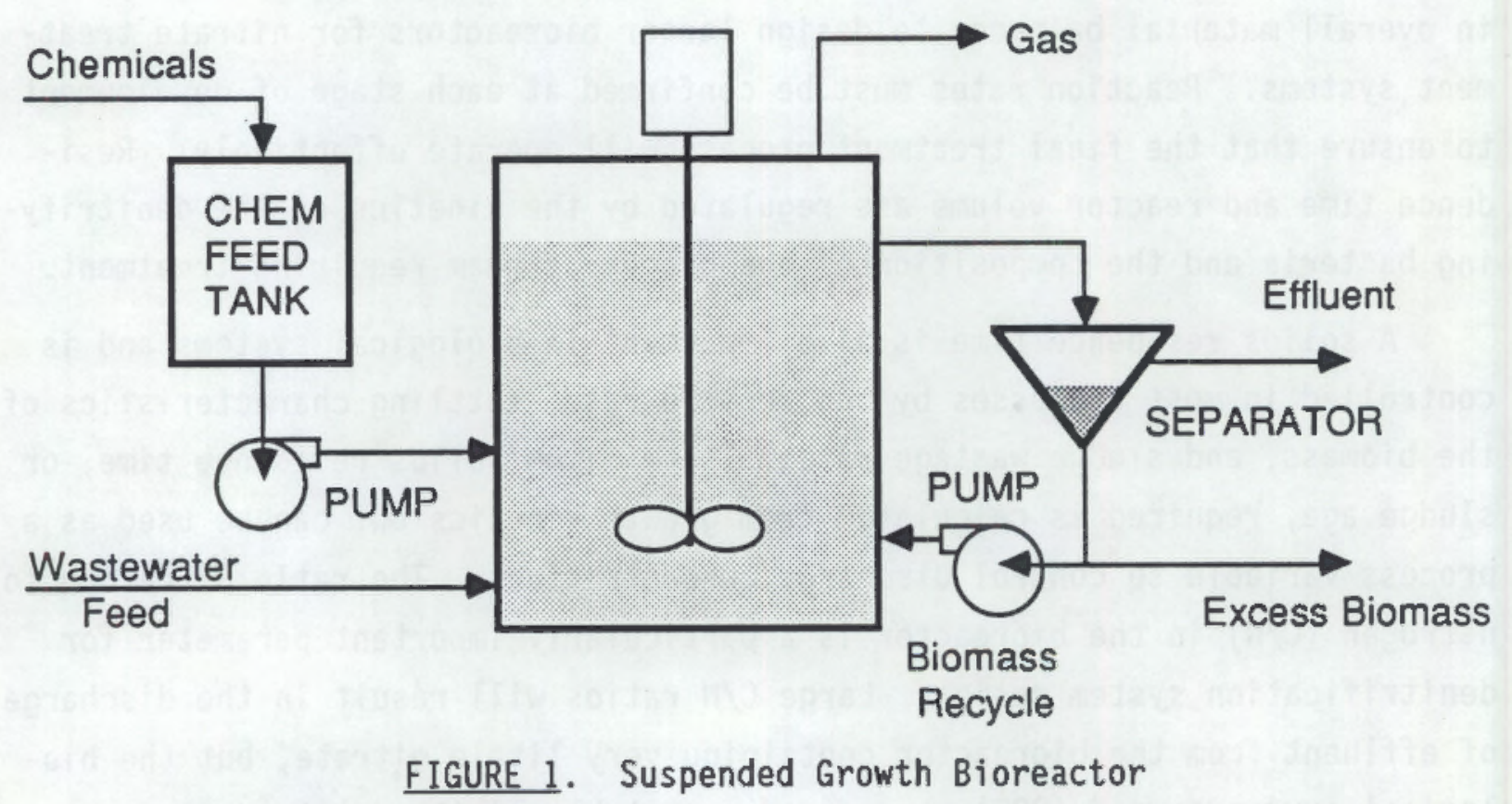


is possible in a suspended-growth reactor. Activated charcoal or coal particles can be used in a fluidized bed process to create a special type of fixed-film reactor (Figure 2). The fluidized bed reactor is better suited for high volumes of waste water with low nitrate concentrations. It is less susceptible to plugging than the fixed bed design and allows high biomass concentrations with a fairly low residence time. However, process control is more difficult with the fluidized bed reactor than the stirred tank bioreactor because variations in feed concentration in the fluidized bed reactor may "shock" the system, killing some of the microorganisms. This usually results in detachment of the organisms from the support matrix, which leads to a washout condition. The stirred-tank bioreactor is less susceptible to upset due to variations in flow rate or feed composition because of the inherent dampening effect of the larger tank volume; it is more appropriate for low volumes with higher concentrations of nitrates. In all bioreactor systems, provisions must be made for feed composition, $\mathrm{pH}$, and temperature control and for separation of the biomass produced by the reaction from the product effluent.

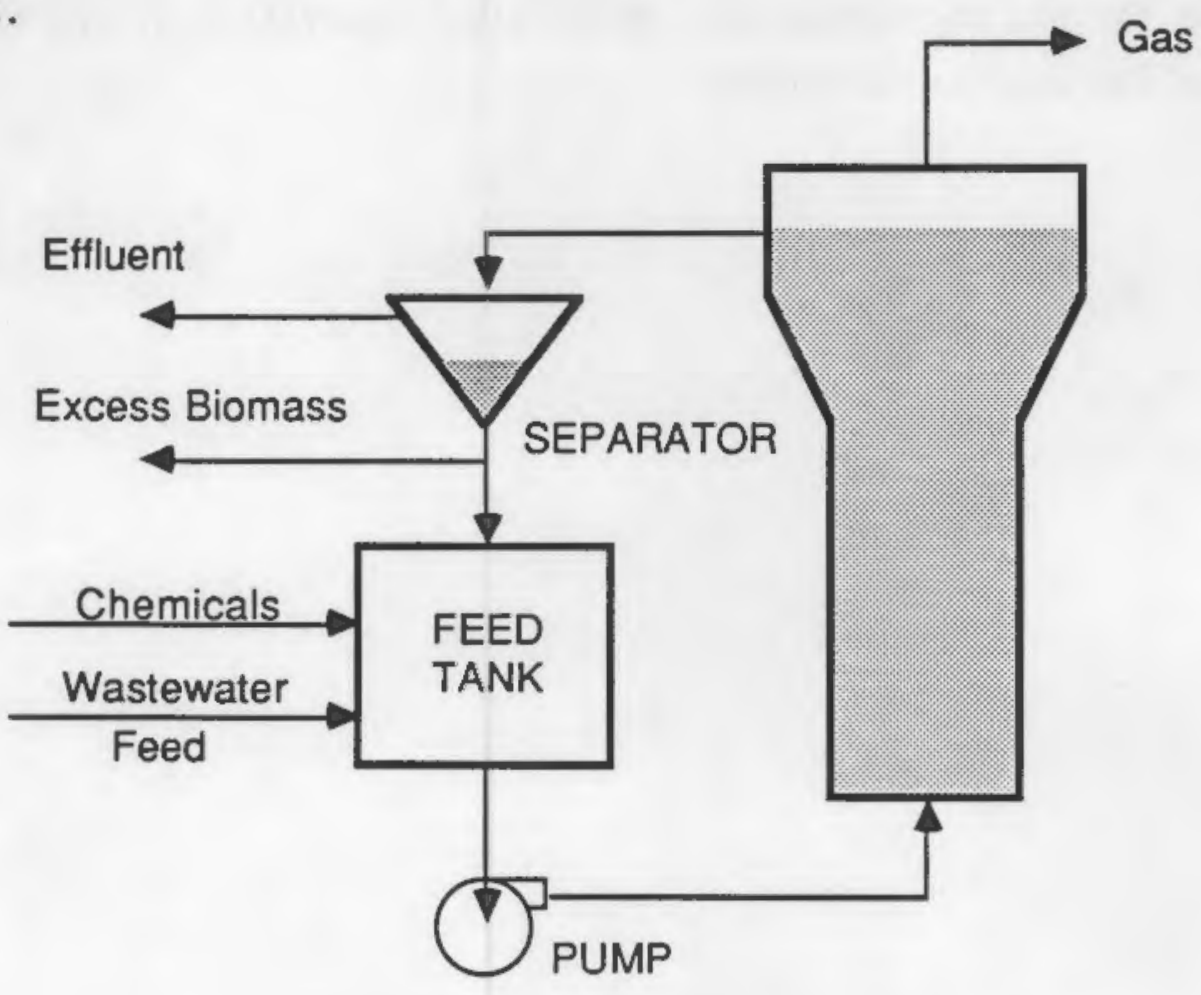

FIGURE 2. Fluidized Bed Bioreactor 
Biological denitrification has been used by several DOE contractors for cleanup of nitrate-containing wastes. Both stirred tank reactors (batch and continuous) and fluidized bed reactors have been used at 0ak Ridge National Laboratory (ORNL) and the 0ak Ridge Y-12 Plant for denitrification of waste waters. Several continuous suspended-growth reactors were developed at the Oak Ridge $\mathrm{Y}-12 \mathrm{Pl}$ ant to denitrify acidic process effluents containing $10 \%$ to 15\% nitrate (Franke, Clark, and Strohecker 1974). A batch biodenitrification technique is routinely used to process nitrate waste water from the 0ak Ridge Y-12 Plant. The batch biodenitrification facility consists of nine 500,000gallon tanks and a water treatment plant.

Fluidized bed microbial denitrification of waste waters was demonstrated by ORNL (Walker et al. 1981) and subsequently employed on a larger scale at the Feed Materials Production Center (FMPC) at Fernald, Ohio (Hopper et al. 1987). The FMPC process uses four 52-ft-tall fluidized bed reactors, each $4 \mathrm{ft}$ in diameter, expanding to $7 \mathrm{ft}$ at the top. The reactors, scaled up from the 0.2-m ORNL pilot-plant bioreactors, also use anthracite coal particles as growth sites for the microorganisms and physical separation of the excess biomass from the aqueous raffinate. 


\section{MICROORGANISM TESTS}

\section{OBJECTIVES OF MICROORGANISM TESTS}

The objective of the microorganism evaluation study was to select denitrifying bacteria that had the ability to destroy nitrates present in process streams and/or groundwater. To reach this objective, two tasks were performed: 1) isolation of denitrifying organisms from a variety of environmental samples; and, 2) characterization of the isolated culture in terms of denitrifying ability and the effect of environmental conditions on denitrification.

The first task focused on selecting suitable denitrifying candidates. Denitrifyers were obtained from various environmental sources including sewage sludge, soil, ponds, and Hanford groundwater and were tested for their effectiveness in reducing the nitrate content.in simulated process waste streams. Potential candidates were inoculated into $100-\mathrm{mL}$ serum bottles containing the simulated waste stream. Nutrients, including acetate, were added and the head space in the bottles was replaced with $\mathrm{N}_{2}$. Acetylene was injected into the bottles to begin the incubation. Acetylene inhibits the conversion of $\mathrm{N}_{2} \mathrm{O}$ to $\mathrm{N}_{2}$ which allows the denitrification process to be assessed by monitoring the production of $\mathrm{N}_{2} \mathrm{O}$.

Once a suitable culture was selected, various environmental parameters were adjusted over a range of values to determine their effect on the rate and extent of biodenitrification. At least three different values for temperature and $\mathrm{pH}$ were tested. Also, different organic electron donors were examined to identify the optimal $\mathrm{C} / \mathrm{N}$ ratio as well as the best carbon source.

\section{MICROORGANISM TEST RESULTS}

Nine cultures, obtained from a variety of environmental sources (Table 1), were tested for their denitrification ability.

Although all cultures could denitrify to some extent, the culture obtained from the Hanford groundwater was selected as the best candidate. This culture could remove approximately $96 \%$ of the nitrate present in test 
TABLE 1. Cultures Tested for Denitrification

\begin{tabular}{cll} 
Isolate & & \multicolumn{1}{c}{ Source of Inoculum } \\
\cline { 1 - 1 } 1 & & Drainage ditch \\
2 & & Farm pond \\
3 & & Columbia River \\
4 & & The Great Salt Lake \\
5 & & Pacific Ocean \\
6 & Dead Sea \\
7 & Greasewood Rhizosphere \\
8 & Hanford Groundwater \\
9 & Soil Sample from ALE Reserve
\end{tabular}

samples (Figure 3 ). In this experiment, nitrate destruction was determined by nitrate analysis of the sample at the conclusion of the experiment. In addition, because it is native to the Hanford environment it has the greatest

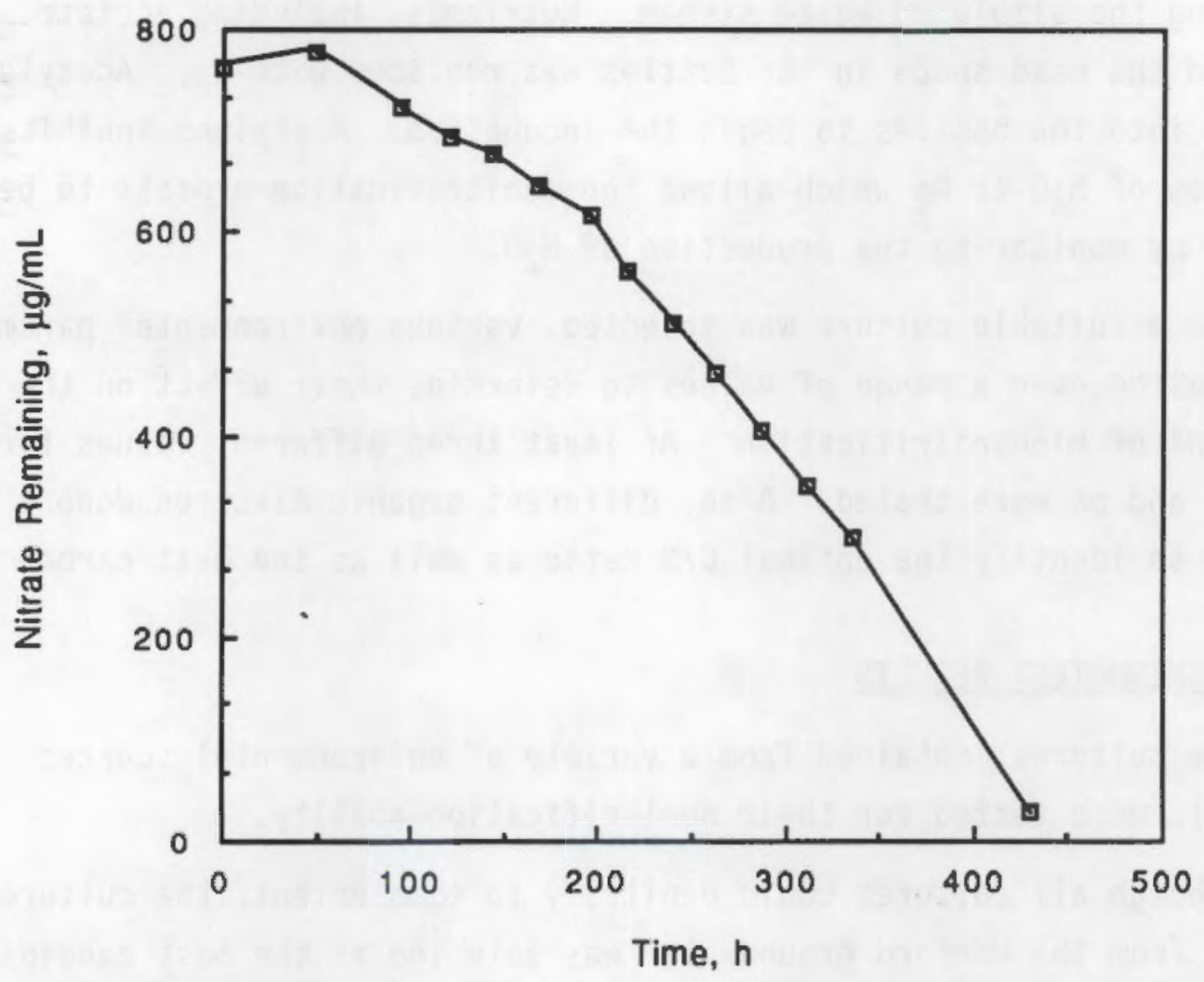

FIGURE 3. Denitrification in a Simulated Waste Stream Inoculated with Denitrifying Culture Obtained from Hanford Groundwaters 
chance for adapting to the environmental conditions likely to be encountered under "rea1 world" conditions (i.e., treatment of Hanford nitratecontaminated groundwater).

As of this writing, the makeup of the Hanford groundwater consortium has not been determined. Efforts to identify and isolate microorganisms responsible for denitrification are planned for FY 1989 and will be reported later.

Following the selection of the Hanford bacteria as the denitrifying culture to be used in further studies, the influence of environmental conditions such as pH, temperature, and carbon source was examined (Table 2). These bacteria appear to favor a slightly alkaline environment and temperatures of approximately $29^{\circ} \mathrm{C}$. Of the three carbon sources examined, the Hanford denitrifyers preferred acetate, although they could grow on methanol and, to some degree, ethanol.

\section{CARBON TETRACHLORIDE TESTS}

The objective of this study was to determine the ability of previously obtained denitrifying organisms to degrade carbon tetrachloride $\left(\mathrm{CCl}_{4}\right)$. The culture obtained from Hanford groundwaters was used in this study. The rationale for using this culture was that, because of its previous exposure to $\mathrm{CCl}_{4}, \mathrm{CCl}_{4}$ degradation ability may already have been enriched. The culture was grown in a nutrient broth containing nitrate. Following growth in the nutrient broth, $0.1 \mathrm{~mL}$ was injected into the samples containing a minimal media amended with ${ }^{14} \mathrm{C}-\mathrm{CCl}_{4}$. Carbon tetrachloride degradation was monitored using ${ }^{14} \mathrm{C}_{-\mathrm{CCl}_{4}}$ and analyzing for ${ }^{14} \mathrm{CO}_{2}$. A flow diagram describing the method is shown in Figure 4.

Results for $\mathrm{CCl}_{4}$ degradation are shown in Figure 5. Approximately $13 \%$ of the added ${ }^{14} \mathrm{C}-\mathrm{CCl}_{4}$ was degraded in the samples inoculated with the Hanford

\section{TABLE 2. Environmental Parameters Influencing Biodenitrification}

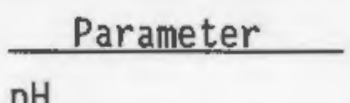

$\mathrm{pH}$

Temperature $\left({ }^{\circ} \mathrm{C}\right)$

Carbon Source
Range Examined

7.95 to 11.58

$24,29,37$

acetate, methanol, ethanol
Optimum value

8

29

acetate 


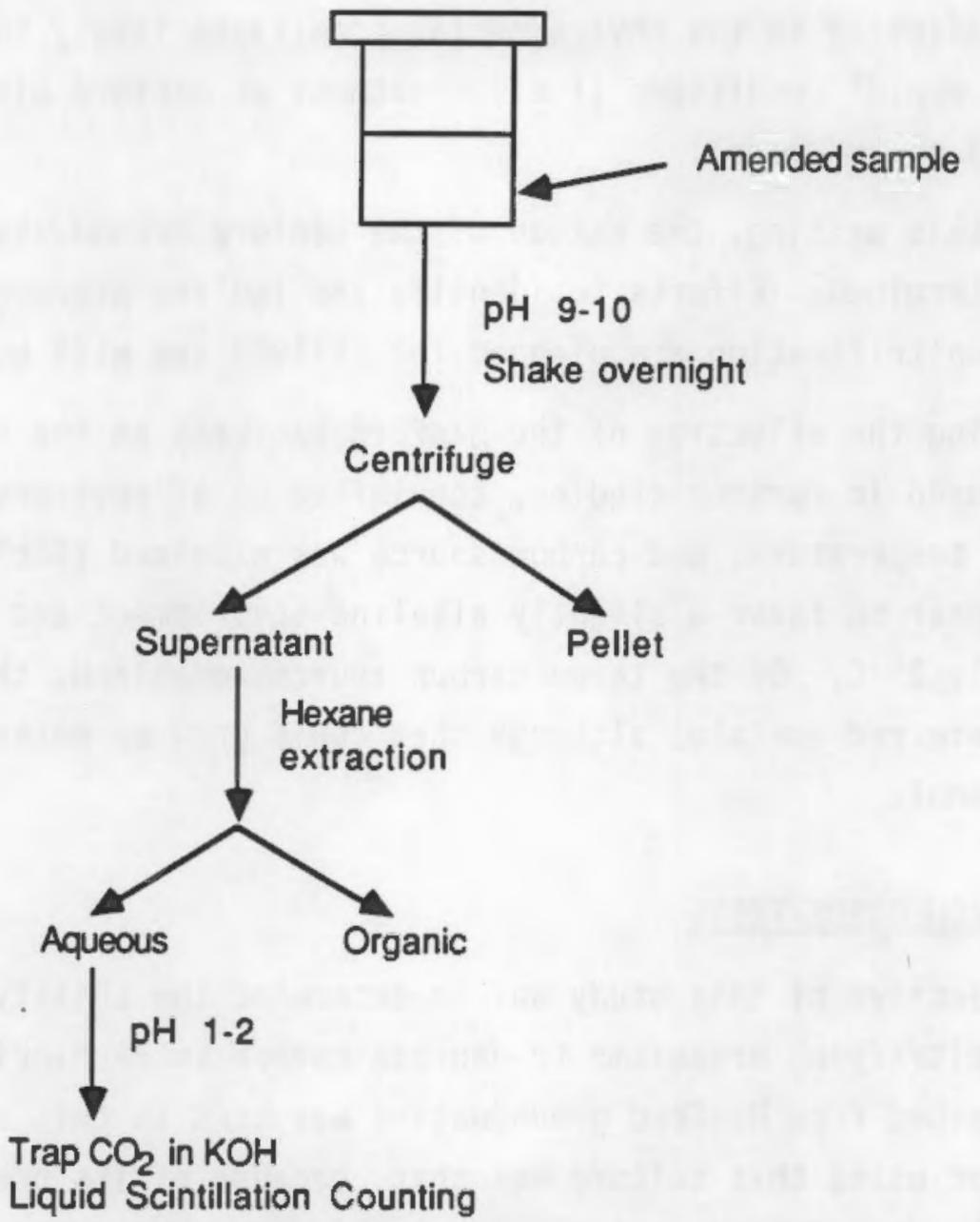

FIGURE 4. Flow Diagram of Method Used for Monitoring ${ }^{14} \mathrm{CO}_{2}$ in Samples

denitrifying culture. In uninoculated samples less than $2 \%$ was degraded or mineralized to nonorganic forms. While the data indicate that $\mathrm{CCl}_{4}$ was degraded by the microorganisms, the percent degraded was less than expected. A mass balance determination of remaining ${ }^{14} \mathrm{C}-\mathrm{CCl}_{4}$ indicated that approximately $50 \%$ of the ${ }^{14} \mathrm{C}-\mathrm{CCl}_{4}$ could not be accounted for. Equipment failure in the initial stages of the experiment forced us to delay sampling by several days. One possibility is that, due to the increased incubation time, ${ }^{14} \mathrm{C}-\mathrm{CCl}_{4}$ and/or ${ }^{14} \mathrm{C}-\mathrm{CO}_{2}$ leaked from the culture tubes. A new experiment is planned to examine this possibility. 


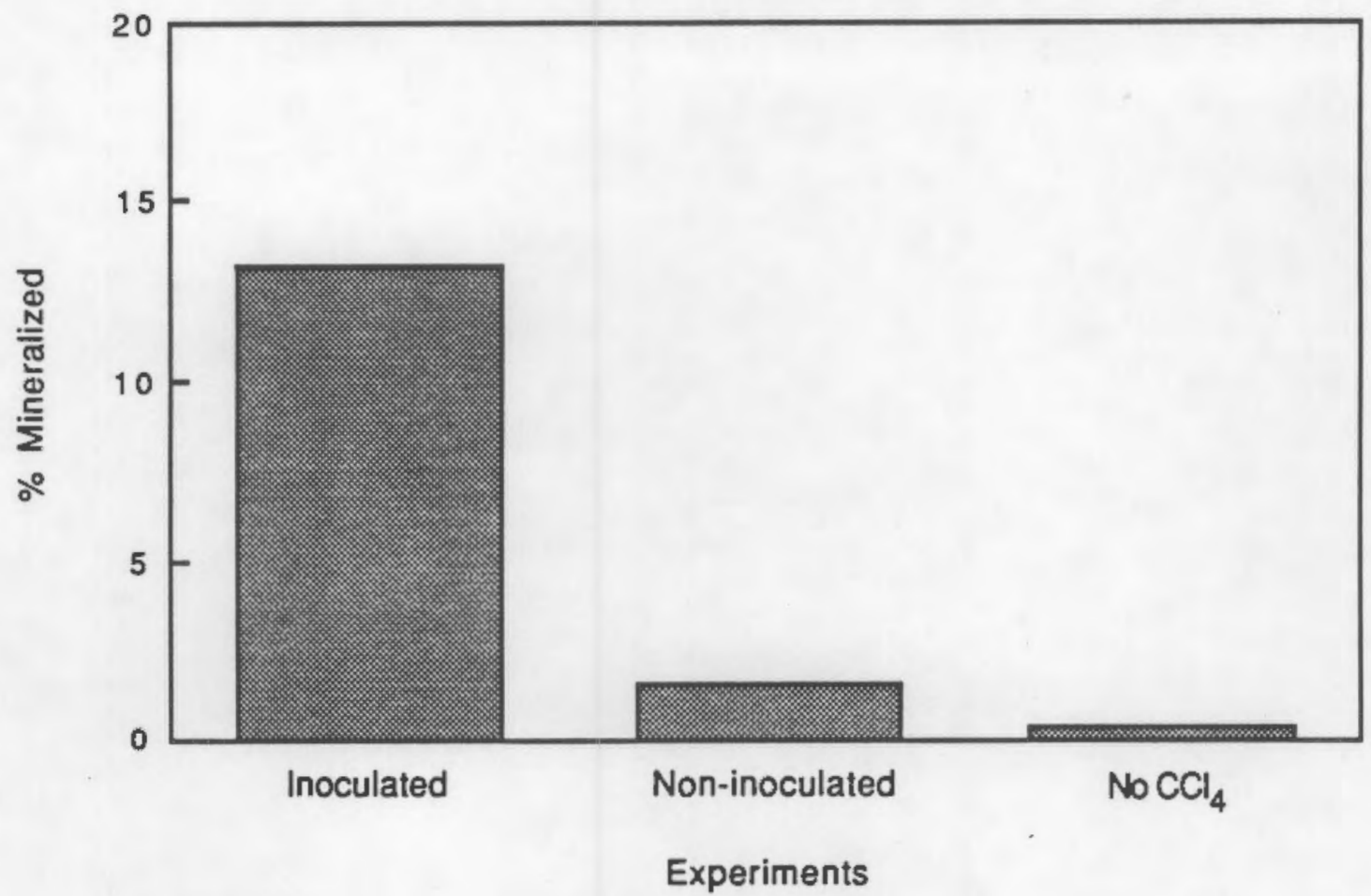

FIGURE 5. $\mathrm{CCl}_{4}$ Degradation in Samples Incubated with Hanford Denitrifying Cultures. Data represent the mean of three replicates.

\section{CARBON TETRACHLORIDE TEST CONCLUSIONS}

The results of this experiment suggest that denitrifying populations indigenous to Hanford groundwaters have developed the ability to degrade $\mathrm{CCl}_{4}$. The mechanism for degradation has not been determined; however, the results of other researchers indicate that $\mathrm{CCl}_{4}$ is hydrolyzed to $\mathrm{CO}_{2}$ by the bacteria (Bouwer and McCarty 1983). 
, 


\section{BENCH-SCALE KINETIC TESTS}

\section{OBJECTIVES OF KINETIC TESTS}

The primary objectives of the bench-scale biodenitrification kinetic tests were to determine denitrification rate constants and to observe the effect of sludge age on nitrate degradation. The goal was to operate continuous flow bioreactors to obtain rate data for identification of an applicable kinetic model. Kinetic constants would then be calculated and used to determine operating conditions for the pilot-scale biodenitrification system.

\section{DESCRIPTION OF KINETIC TESTS}

Four continuous-flow non-recycle bioreactors (one 5-L and three 8-L) were operated at 5-, 8-, 12-, and 20-day residence times to obtain substrate utilization kinetics. Because the reactors were operated without solids recycle, the solids residence time through the reactor is equivalent to the hydraulic residence time. The reactors were operated for a minimum of 65 days to ensure that a steady state was achieved for each reactor during the test period. Steady-state was identified when the suspended solids, nitrate, and acetate concentrations stabilized to within $\pm 20 \%$ of the mean value over a five- to ten-day period. The bioreactors used magnetic stirrers, peristaltic feed pumps, and stoppered covers during operation. The feed solution consisted of simulated groundwater (Grande Ronde Number 4) to which was added sodium nitrate to raise the concentration of nitrate to $1500 \mathrm{mg} / \mathrm{L}$. Acetic acid was added as the carbon source. The bioreactors were inoculated with the culture of microorganisms indigenous to the Hanford groundwater that were obtained from laboratory testing.

To monitor reactor performance and obtain the necessary data for kinetic rate determination, samples were removed daily from each of the reactors and the feed stream. A minimum of three samples per week were analyzed for chemical oxygen demand (COD), acetate, nitrate and nitrite, total suspended solids (MLSS), and volatile suspended solids (MLVSS). Temperature, pH, and feed flowrate were also recorded daily. 


\section{RESULTS OF KINETIC TESTS}

The steady-state concentrations obtained for each of the four continuous reactors are shown in Table 3 . An equivalent nitrate concentration was calculated to account for nitrate partially reduced to nitrite. The equivalent concentration was used in all kinetic calculations. The microbial growth and substrate utilization kinetics were first assumed to follow the Monod model with acetate as the limiting substrate. Although a linear relationship was obtained, a negative intercept was calculated. Negative intercepts result in negative values for both the rate constant and the endogenous decay constant. This indicates that the Monod model does not adequately describe the reaction kinetics. Various kinetic expressions including first- and second-order

TABLE 3. Steady-State Operating Conditions

\begin{tabular}{|c|c|c|c|c|}
\hline Reactor Residence Time (Days) & 5 & 8 & 12 & 20 \\
\hline \multicolumn{5}{|l|}{ Inlet Concentrations (mg/L) } \\
\hline COD & 1310 & 1310 & 1310 & 1340 \\
\hline Acetate & 1650 & 1650 & 1520 & 1500 \\
\hline Nitrate $\left(\mathrm{NO}_{3}^{-}-\mathrm{N}\right)$ & 329 & 329 & 344 & 374 \\
\hline \multicolumn{5}{|l|}{ Outlet Concentrations $(\mathrm{mg} / \mathrm{L})$} \\
\hline COD & 556 & 361 & 351 & 369 \\
\hline Acetate & 722 & 462 & 398 & 297 \\
\hline Nitrate $\left(\mathrm{NO}_{3}^{-}-\mathrm{N}\right)$ & 158 & 42 & 72 & 72 \\
\hline Nitrite $\left(\mathrm{NO}_{2}^{-}-\mathrm{N}\right)$ & 43 & 10 & 0 & 29 \\
\hline $\operatorname{MLSS}(a)$ & 93 & 97 & 89 & 46 \\
\hline $\operatorname{MLVSS}(\mathrm{b})$ & 44 & 55 & 48 & 37 \\
\hline \multicolumn{5}{|l|}{ Calculated Values } \\
\hline Total Equivalent $\mathrm{NO}_{3}-\mathrm{N}(\mathrm{mg} / \mathrm{L})$ & 184 & 48 & 72 & 89 \\
\hline $\mathrm{C} / \mathrm{N}(\mathrm{mg} / \mathrm{mg})$ & 2.62 & 1.73 & 1.69 & 1.72 \\
\hline$\%$ Volatile Solids & 47 & 57 & 54 & 80 \\
\hline
\end{tabular}

(a) Biomass concentration - as-mixed liquor suspended solids (total biomass).

(b) Biomass concentration - as-mixed liquor volatile suspended solids (estimate of active biomass). 
models were also evaluated with both acetate and nitrate as the limiting substrate. The first order expression shown in Equation (4), with acetate as the limiting substrate, most accurately described the bench-scale data. Equations (6) and (7) identify the nitrate and biomass balances that were used with Equation (1) to generate linear equations for determining the rate constant $k$, the biomass yield and decay constants $Y_{B}$ and $K_{d}$, and the nitrate yield $Y_{N}$.

$$
\begin{aligned}
& d N / d t=Y_{N}(-d S / d t)=Y_{N}(k X S) \\
& d X / d t=Y_{B}(k \times S)-K_{d} X
\end{aligned}
$$

Material balance expressions were developed for acetate and biomass as shown in Equations (8) and (9), respectively. Linear regressions of the data using the material balance expressions are shown in Figures 6 and 7 . Kinetic

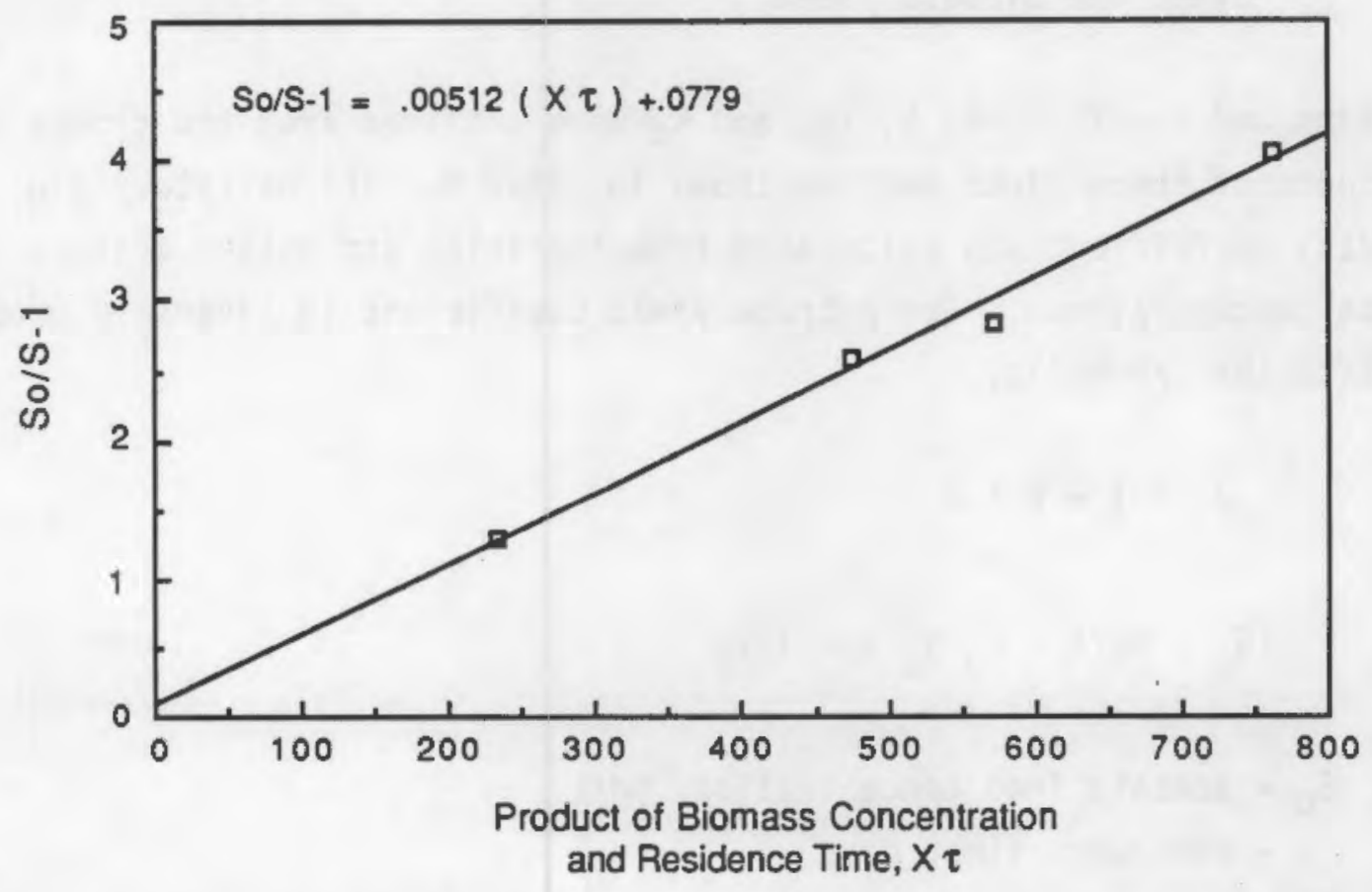

FIGURE 6. Substrate Removal Efficiency $\left(\mathrm{S}_{0} / \mathrm{S}-1\right)$ as a Function of Biomass Concentration and Residence Time $(X \tau)$ (substrate material balance used to calculate reaction rate constant $k$ ) 


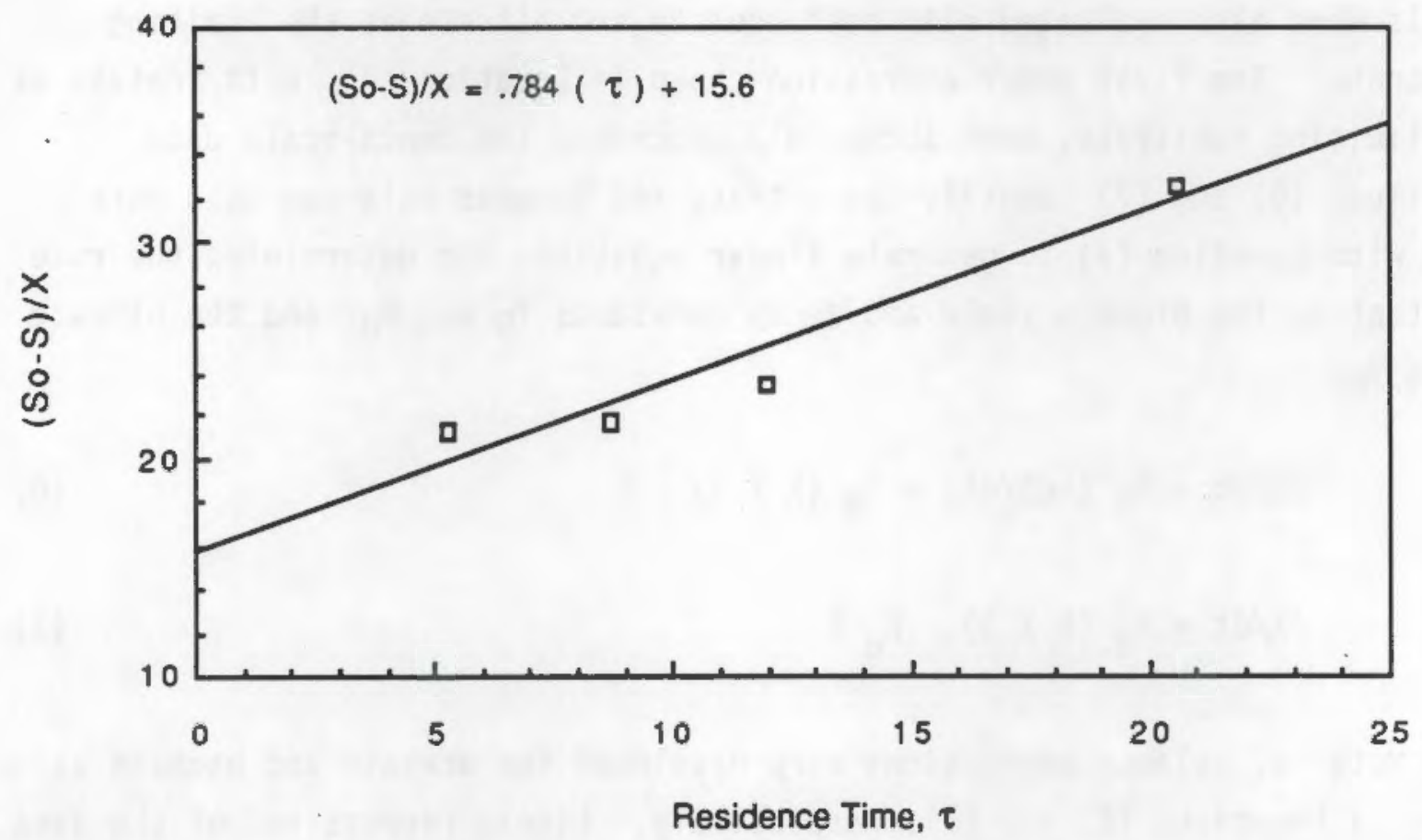

FIGURE 7 . Substrate Yield $\left(\left(S_{0} \cdot S\right) / X\right)$ as a Function of Residence Time $(\tau)$ (microorganism material balance used to calculate decay coefficient and biomass yield)

constants and coefficients $k, Y_{B}$, and $K_{d}$ were obtained from the slopes and intercepts of these plots and are shown in Table 4 . The nitrate yield (removal) coefficient was calculated from the inlet and outlet acetate and nitrate concentrations. The nitrate yield coefficient is inversely proportional to the $\mathrm{C} / \mathrm{N}$ ratio.

$$
\begin{aligned}
& S_{0} / S-1=k X \tau \\
& \left(S_{0}-S\right) / X=K_{d} / Y_{B} \tau+1 / Y_{B}
\end{aligned}
$$

where $S_{0}=$ acetate feed concentration, $\mathrm{mg} / \mathrm{L}$

$\tau=$ residence time, days

$X=$ biomass concentration.

In addition to developing the kinetic expression adequate for modelling the denitrification reaction, estimates of the optimum $\mathrm{C} / \mathrm{N}$ ratio and sludge 
IABLE 4. Calculated Kinetic Constants

\begin{tabular}{|c|c|}
\hline Constant & Value \\
\hline$k$ (mg MLVSS-day/L) $^{-1}$ & 0.0051 \\
\hline$K_{d}(\text { day })^{-1}$ & 0.050 \\
\hline$Y_{B}$ (mg MLVSS/mg acetate) & 0.064 \\
\hline$Y_{N}\left(m g\left(\mathrm{NO}_{3}-\mathrm{N}\right) / \mathrm{mg}\right.$ acetate $)$ & 0.217 \\
\hline
\end{tabular}

age were obtained. As shown in Table 3 , the $\mathrm{C} / \mathrm{N}$ ratio ranged from 1.69 to 2.62. The minimum $\mathrm{C} / \mathrm{N}$ ratio was obtained at a sludge age of 12 days. The pilot-scale bioreactor should be operated at a sludge age of 8 days or greater to maximize nitrate metabolism and minimize the acetate required. The reactors were operated between $26^{\circ} \mathrm{C}$ and $35^{\circ} \mathrm{C}$ at a pH of 6.8 to 7.8 . The optimum temperature and $\mathrm{pH}$ were not evaluated; however, results from other denitrification operations indicate that optimum denitrification occurs near $29^{\circ} \mathrm{C}$ and a pH of 7.5 (Knowles 1982).

Results of the bench-scale kinetic tests were used to set preliminary operating conditions for a pilot-scale bioreactor system. However, the presence of residual nitrites and low percentage of volatile suspended solids $(<80 \%)$ in several of the bench-scale bioreactors indicates that culture conditions may not have been at an optimum for microbial growth and metabolism. The addition of more than $300 \mathrm{mg} / \mathrm{L}$ of $\mathrm{NO}_{3}^{-}-\mathrm{N}(2 \mathrm{~g} / \mathrm{L}$ sodium nitrate) to the simulated groundwater may have elevated the total sodium concentration to an inhibitory level. Therefore, denitrification tests will be continued in FY 1989 along with bench-scale tests to confirm $\mathrm{CCl}_{4}$ degradation. 


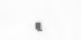

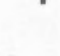

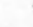

-

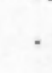




\section{PILOT-SCALE BIOREACTOR TESTS}

A pilot-scale bioreactor system was designed, constructed, and installed at the 324 Building in the 300 Area in FY 1988. The pilot plant was subsequently tested and operated with a microorganism culture developed in laboratory experiments. Although the bioreactor has not been operated long enough to reach steady state, and hence allow us to determine system capacities, denitrification to less than drinking water standards was demonstrated with a 220-ppm nitrate feed at a $1 \mathrm{~L} / \mathrm{h}$ feed rate.

\section{OBJECTIVES OF PILOT-SCALE TESTS}

The primary objective of pilot-scale biotechnology testing is to demonstrate the feasibility of using denitrifying bacteria for the destruction of carbon tetrachloride at a scale large enough to develop engineering data for a full-scale system evaluation. This task is being accomplished through a two-year design and testing effort that began in FY 1988. Specific goals for FY 1988 were to design, construct, install, and begin operating a pilot-scale biotreatment process. These goals were successfully accomplished as described below.

Goals for FY 1989 and FY 1990 will be to determine operating conditions and kinetics associated with simultaneous denitrification and destruction of organics using the pilot-scale testing facility. The objective will be to provide sufficient baseline data to support the design of a full-scale biotreatment process that can be used to denitrify and remove various organics, including carbon tetrachloride, from contaminated Hanford groundwaters and process effluents.

The FY 1988 pilot-scale demonstration effort consisted of three major technical tasks: 1) bioreactor and pilot-plant design, 2) pilot-plant fabrication and installation, and 3) pilot-plant testing.

Task 1, Bioreactor and Pilot-Plant Design

A continuously operated, 50-L stirred tank reactor was selected as a design basis for the pilot-scale process. This reactor configuration has the inherent advantage of being more immune to process upsets (changes in feed 
composition or other operating conditions) than plug flow configurations. Another advantage is that the mathematical models needed to describe the global kinetics associated with stirred tank reactors are readily available. These models account for the heterogeneous heat and mass transfer processes that modify the intrinsic reaction kinetics, as determined by bench-scale testing. By choosing a conventional reactor configuration, a major modelling effort to develop full-scale design equations is avoided. The process flow diagram shown in Figure 8 and the flowsheet shown in Table 5 were developed. The bioreactor and clarifier designs and the process instrumentation were developed with the assistance of PNL staff experienced in the design and operation of continuous fermentation systems.

\section{Task 2, Pilot-Plant Fabrication and Installation}

Under this task, the pilot-plant equipment was procured and installed. off-site vendors fabricated and assembled the bioreactor and associated equipment and instruments on a skid-mounted modu?. A skid-mounted module was selected to facilitate installation and ease final disposal of the equipment. The pilot-plant module was installed in the EDL-101 facility located in the 324 Building.

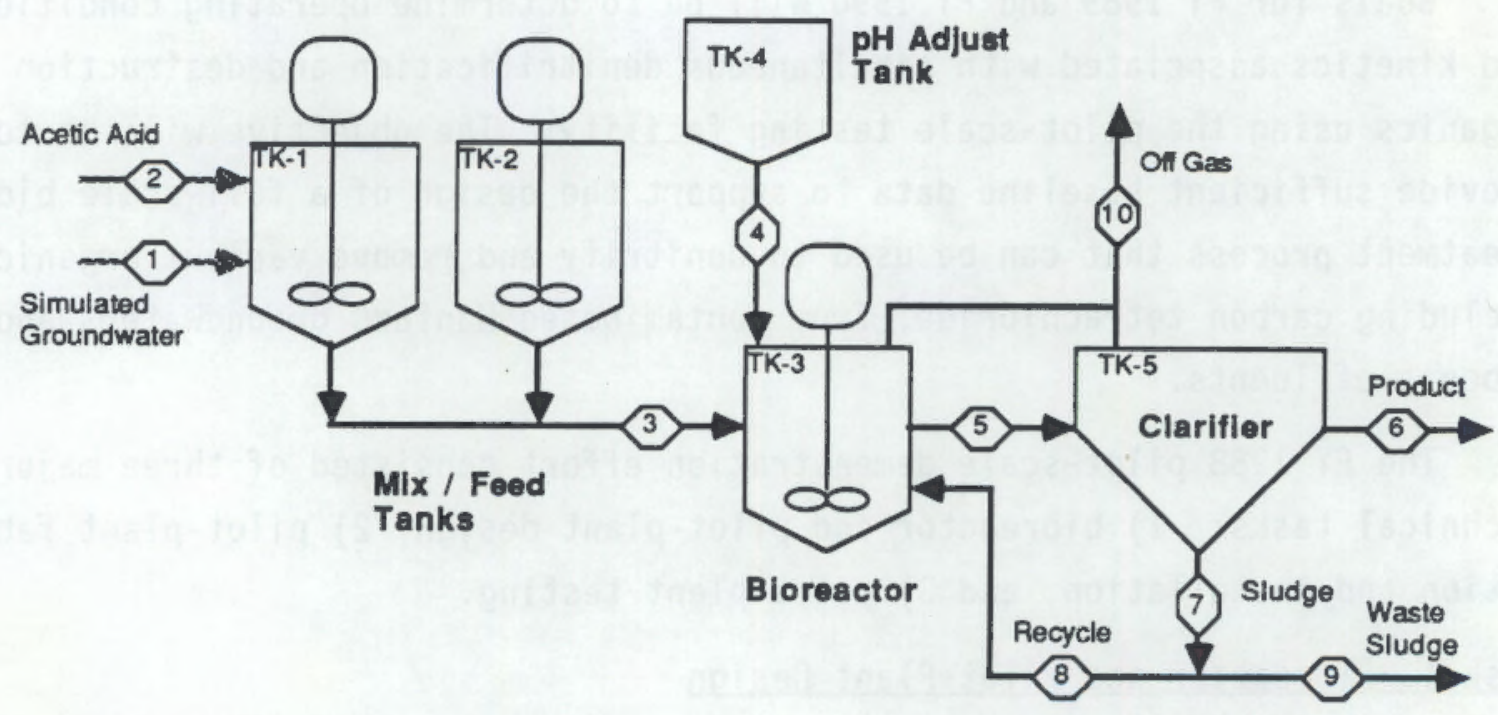

FIGURE 8. Flow Diagram of Biodenitrification Pilot-Plant 


\section{IABLE 5. Biodenitrification Pilot-Plant Flowsheet}

\begin{tabular}{|c|c|c|c|c|c|c|c|c|c|c|}
\hline BASIS: & & & & & & & & & & \\
\hline Bioreactor Temperature & T & 29 & ${ }^{\circ} \mathrm{C}$ & & & & & & & \\
\hline Acetate rate consianl & $k$ & 0.00512 & L/day $\cdot m g$ MLV & vss & & & & & & \\
\hline Decar Conslant & Kd & 0.0503 & \begin{tabular}{|l|}
$1 /$ day \\
\end{tabular} & & & & & & & \\
\hline Biomass Yield Coelficient & $\mathrm{na}$ & 0.0641 & mq MLVSS/mg & Acotate & & & & & & \\
\hline Nitrate Destruction Coelficient & $Y_{n}$ & .961 & $\mathrm{mg} \mathrm{NO} 3 / \mathrm{mg} \mathrm{Ac}$ & colale & & & & & & \\
\hline Feed Nitrate Concentration & CNO & 400 & $\begin{array}{ll}\mathrm{mgh} \\
\end{array}$ & & & & & & & \\
\hline Efiluent Nitrale Concentration & ONOE & 44 & $\mathrm{mg} \Omega$ & & & & & & & \\
\hline Feed Acelate Conceniration & CACO & 551 & $\mathrm{mgh}$ & & & & & & & \\
\hline Bioreacior Volume & VBR & 50 & L & & & & & & & \\
\hline Feed Flowrale & a & 240 & Uday & & & & & & & \\
\hline Residence Time & Tau & 0.21 & day & & & & & & & \\
\hline Seltled Biomass Concentration & $x_{4}$ & 3000 & $\mathrm{mgh}$ & & & & & & & \\
\hline Produa Biomass Concentratior & $x p$ & 1.0 & $\mathrm{mg} / \mathrm{h}$ & & & & & & & \\
\hline Sludge Age & Thesa & 112 & day & & & & & & & \\
\hline & & & & & & & & & & \\
\hline & & & & & & & & & & \\
\hline Siream * & 1 & 2 & 3 & 4 & 5 & 6 & 7 & 8 & 9 & 10 \\
\hline Description & Groundwater & Acetic Acid & Feed & $\mathrm{NEOH}$ & Elfluent & Producl & Sludge & Recrcle & Waste & OffGas \\
\hline MASS FLOWS & & & & & & & & & & \\
\hline Water ( $\mathrm{g} /$ day $)$ & 239904 & 2350 & 242254 & 846 & 684751 & 243288 & 441805 & 441592 & 213 & \\
\hline Nitrale ( $g /$ day) & 96.0 & & 96.0 & & 28.6 & 10.7 & 18.9 & 18.9 & .213 & \\
\hline Acelic Acid ( $Q /$ day) & & 134 & 134 & & & & & & & \\
\hline $\mathrm{NaOH}(\mathrm{g} /$ day $)$ & & & & 34.5 & & & & & & \\
\hline Biomass (g/dar) & & & & & 1293 & 243 & 1287 & 1286 & .619 & \\
\hline N2 (std L(h) & & & & & & & & & & .603 \\
\hline $\mathrm{CO} 2(\mathrm{~s} 1 \mathrm{~d} \mathrm{~L} / \mathrm{h})$ & & & & & & & & & & .969 \\
\hline H2O Vapor (sid LM) & & & & & & & & & & .089 \\
\hline DENSITY (g/mL) & 1.00 & 1.02 & 1.00 & 1.02 & 1.01 & 1.00 & 1.03 & 1.03 & 1.03 & \\
\hline TOTAL FLOW (L/day) & 240 & 2.44 & 242 & .863 & 672 & 243 & 429 & 429 & .206 & 39.9 \\
\hline CONCENTRATIONS & & & & & & & & & & \\
\hline Nitrate $(\mathrm{mg} / \mathrm{L})$ & 400 & & 396 & & 44.0 & 44.0 & 44.0 & 44.0 & 44.0 & \\
\hline Acelic Acid (g/) & & 55.2 & .555 & & .180 & & & & & \\
\hline $\mathrm{NaOH}(\mathrm{g} \Omega)$ & & & & 40 & & & & & & \\
\hline Biomass $(\mathrm{mg} / \mathrm{L})$ & & & & & 1925 & 1.00 & 3000 & 3000 & 3000 & \\
\hline N2 ( $\mathrm{vol} \%)$ & & & & & & & & & & 36.3 \\
\hline $\mathrm{CO} 2(\mathrm{vol} \%)$ & & & & & & & & & & 58.3 \\
\hline H2O Vapor (vol \%) & & & & & & & & & & 5.38 \\
\hline
\end{tabular}




\section{Task 3, Pilot-Plant Testing}

Under this task, all testing procedures and methodologies were established and a detailed two-year test $\mathrm{pl}$ an was developed. The test $\mathrm{plan}$ underwent peer review as well as review by the line manager of PNL's Process Development Section, a safety engineer, a quality assurance engineer, and the building manager. Batch start-up of the pilot-plant was successfully accomplished, demonstrating the removal of nitrates from a simulated groundwater. The specific goals of the overall pilot-plant testing task are to:

- Determine the operability of the pilot-scale equipment through shakedown tests with water and then with the mixed biological culture used in microorganism tests.

- Operate the bioreactor in a batch mode to cultivate sufficient quantities of biomass for continuous operation.

- Demonstrate continuous biological denitrification of a simulated nitrate-bearing groundwater through extended operation (Phase I, FY 1988/89).

- Demonstrate continuous biodegradation of simulated nitrate- and $\mathrm{CCl}_{4}$-contaminated groundwater through extended operation (Phase II, FY 1989).

- Demonstrate biological treatment of actual groundwater and waste waters (Phase III, FY 1989 or FY 1990).

Test data that will be obtained in FY 1989 include denitrification and organic destruction rates, and identification of optimal bioreactor temperatures, flowrates, and $\mathrm{pH}$.

\section{DESCRIPTION OF PILOT-SCALE EQUIPMENT}

The pilot-scale biodenitrification system consists of two waste-water feed tanks; a continuous stirred-tank bioreactor; a biomass settling tank or clarifier; and pressure, temperature, off-gas $\mathrm{CO}_{2}$, and $\mathrm{pH}$ monitoring and control equipment. Figures 9, 10, and 11 are photographs of the process equipment. 


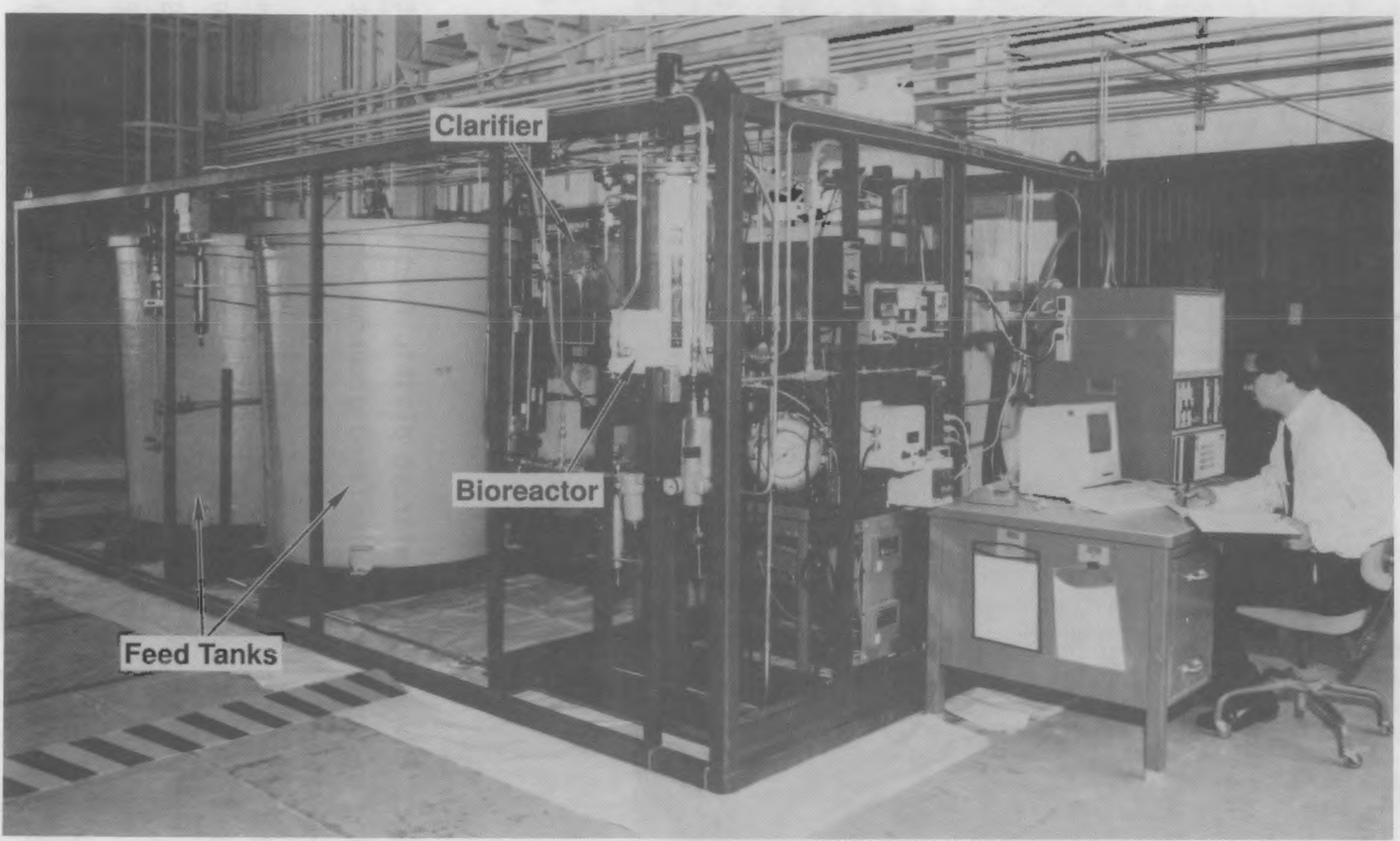

FIGURE 9. Bioreactor and Process Control Instrumentation 


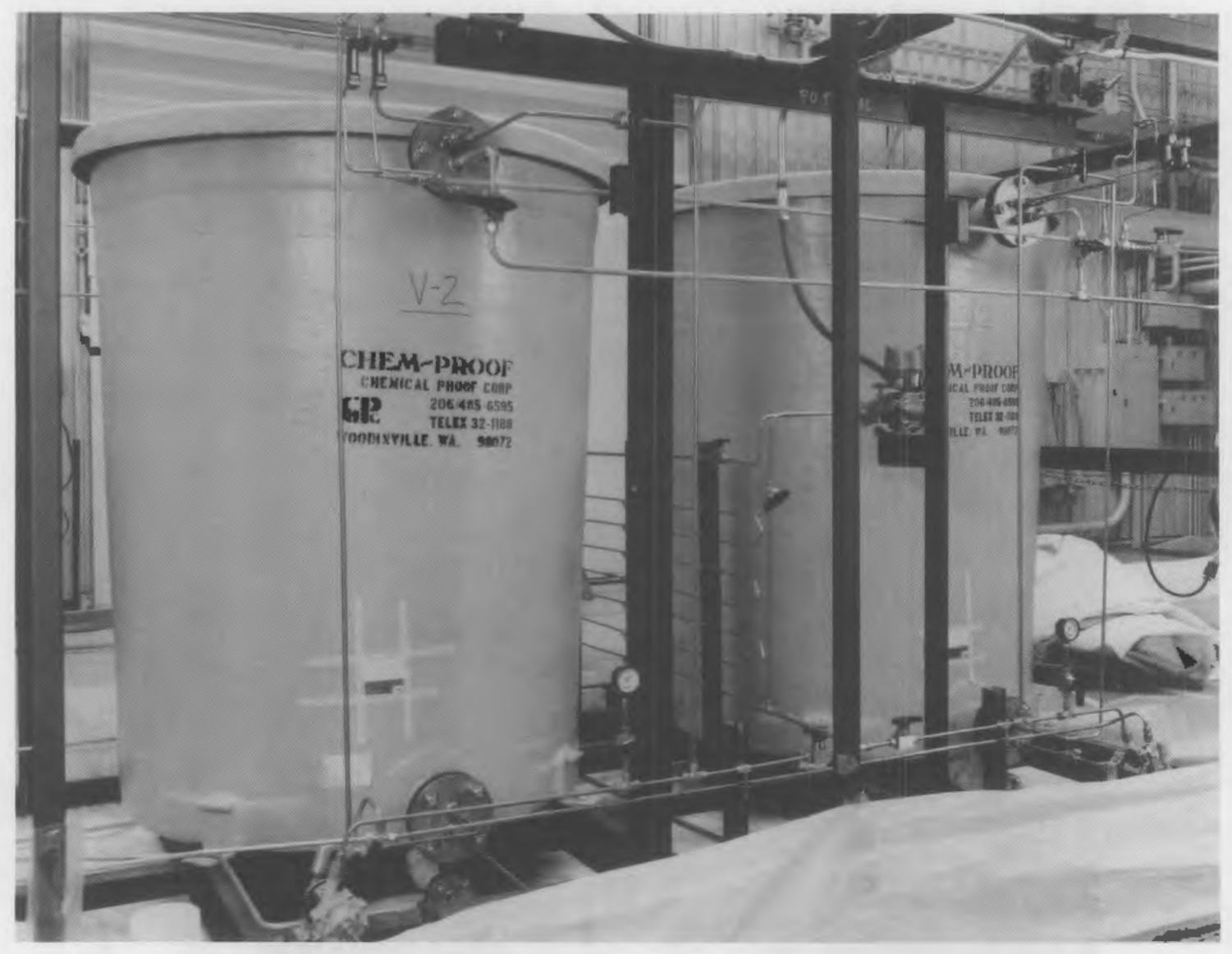

FIGURE 10. Bioreactor Feed Tanks

Feed Tanks

Two 490-gal fiberglass-reinforced plastic feed tanks are used to supply nitrate-bearing waste water or simulated groundwater to the bioreactor. The feed tanks are shown in Figure 11. With a design feed flow rate of $240 \mathrm{~L} /$ day, each feed tank is capable of supplying 7 days of groundwater to the bioreactor. Having two feed tanks enables the extended continuous operation of the process without requiring a downtime for restocking the feed solutions. Level controllers and indicators are incorporated in the feed tanks to ensure an uninterrupted supply of feed to the bioreactor. A concentrated acetic acid solution is also fed to the bioreactor via a low-flow metering pump from a 2.5 -gal polypropylene container. 


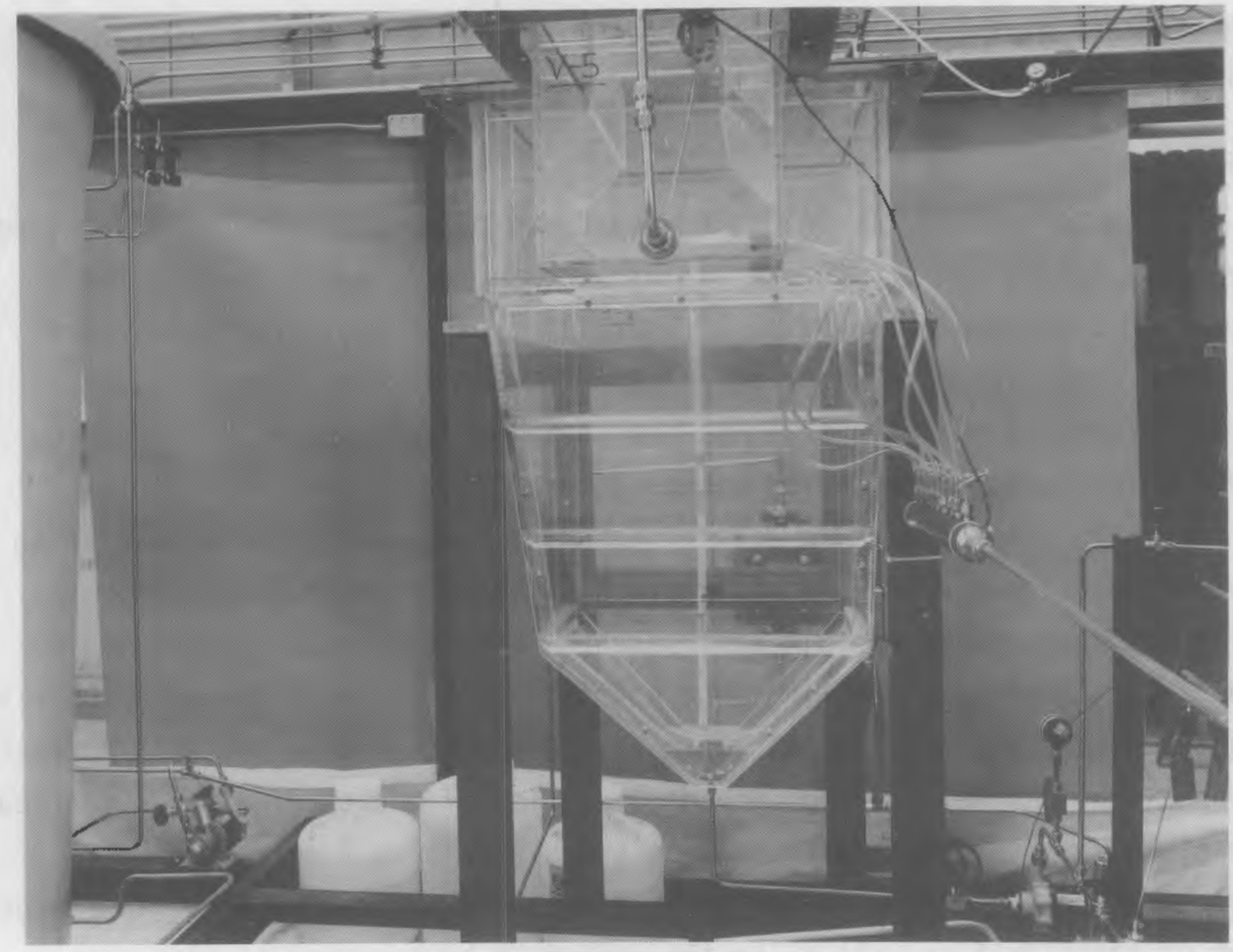

\section{FIGURE 11. Clarifier}

\section{Bioreactor}

The $50-\mathrm{L}$ bioreactor is a cylindrical 304L stainless steel vessel $2-\mathrm{ft}$ tall and 14-in. in diameter. The bioreactor can be seen in the center of the process module photograph in Figure 9 . To ensure adequate agitation, the bioreactor design incorporates four internal baffles and two flat-blade impellers driven by a $1 / 8 \mathrm{hp}$ variable-speed motor. An acrylic sight glass is provided in the reactor wall for viewing the suspension culture. Thermocouples and a submersible $\mathrm{pH}$ electrode are included for monitoring. External heaters located on the sides of the vessel maintain internal operating temperatures. The reactor is designed for $1-$ to $2-\mathrm{g} / \mathrm{L}$ suspended solids (dry weight of microorganisms) and a residence time of $\sim 5 \mathrm{~h}$. To operate under 
anaerobic or anoxic conditions, the reactor is sealed from the ambient air using neoprene gaskets on the vessel cover and an integral rotating seal for the impeller shaft.

\section{Clarifier}

The reactor effluent, containing suspended biomass, is fed to a settling vessel (clarifier) to recover the biomass for recycle and to clarify the denitrified simulated groundwater. Figure 11 is a photograph of the clarifier. The clarifier is constructed of 3/8-in. and 1/2-in. clear acrylic sheets and consists of both aeration and settling zones. Air is introduced through porous ceramic diffusion stones into a $13-\mathrm{L}$ aeration zone of the clarifier. In this elevated oxygen environment, the microorganisms shift to aerobic metabolism and consume any residual acetate. In addition, biomass settling is enhanced in aerobic environments where the bacteria tend to agglomerate. The $280-\mathrm{L}$ settling zone consists of a sloped base which funnels the settled biomass to a bottom exit port. A V-notched weir and exit port at the upper liquid level provides an adequate flow of denitrified and clarified effluent while retaining biomass within the clarifier. A recycle pump is incorporated for returning concentrated biomass to the bioreactor. The large volume of the clarifier will allow the system to be operated at flow rates greater than ten times the reactor design values.

\section{pH-Control/Adjust System}

To maintain an optimum $\mathrm{pH}$ for biomass growth and metabolism, the bioreactor is equipped with a $\mathrm{pH}$-control system. During denitrification, the $\mathrm{pH}$ of the reactor contents increases due to the formation of hydroxide $\left(\mathrm{OH}^{-}\right)$ ions. Although the acetic acid feed solution may help neutralize excess $\mathrm{OH}^{-}$, a pH-control system is present to maintain an ideal pH of between 7 and 8 . Dilute sulfuric acid or sodium hydroxide can be introduced to neutralize the hydroxide or hydrogen ions, respectively. A ph-adjust tank containing the appropriate solution is mounted for gravity feed through a bellows valve to the bioreactor. The $\mathrm{pH}$ probe installed in the reactor is connected to both monitoring and control systems. Deviations from the set point $\mathrm{pH}$ open the $\mathrm{pH}$ adjust valve and result in neutralization of excess $\mathrm{OH}^{-}$or $\mathrm{H}^{+}$. An oversized 
spill container filled with calcium carbonate is located below the $\mathrm{pH}$-adjust tank and valves to contain and neutralize acid or base in the event of a spill or leak.

\section{Process Control}

Operation of the biodenitrification process is conducted from four main control points: a feed flow controller, a recycle flow controller, and the bioreactor $\mathrm{pH}$ controller. The flow controllers are of the proportionalintegral-derivative (PID) type and are located in the process instrument cabinet as shown in Figure 9. Flow rates are maintained by feedback from various flow monitoring devices. The bioreactor $\mathrm{pH}$ is maintained by an on-off controller built into a Chemtrix Mode1 45A pH meter. The pH set point is adjusted at the front panel of the $\mathrm{pH}$ meter. The bioreactor system is designed to run unattended during evenings and over weekends. Control valves are the "fail-close" type and will terminate feed flow if power is interripted. In addition, a solenoid-operated "fail-open" valve will stop feed flow if the bioreactor high-level sensor is tripped.

\section{Data Acquisition}

A11 process temperatures, flows, bioreactor $\mathrm{pH}$, and the off-gas $\mathrm{CO}_{2}$ concentration are monitored and recorded electronically for real-time display and data analysis. The data acquisition system consists of a Hewlett Packard model $3497 \mathrm{~A}$ data logger and a Macintosh ${ }^{\circledR}$ SE computer with an internal 20-megabyte hard disk. The sampling frequency, monitoring points, data display, and data recording are controlled by the computer using National Instruments Labview software. Labview provides the operator with a graphically simulated instrument panel on the computer screen that allows the operator to visually monitor the process and specify the data display update and data-storing frequencies. No process control is performed from the

\footnotetext{
- Macintosh is a registered trademark of Apple Computer, Inc., Cupertino, California.

(a) Labview is a registered trademark of National Instruments, Austin, Texas.
} 
computer or the HP data logger as the controllers are "stand-alone." Data stored on the hard disk will be available for analysis using other software at the end of each experiment.

\section{PILOT-SCALE TEST METHODOLOGY}

The primary factors that affect denitrification kinetics include temperature, $\mathrm{pH}$, hydraulic residence time, solids detention time, biomass concentration, and substrate concentrations. Small changes in any of these operating parameters can greatly influence effluent and biomass concentrations, settling characteristics, and reactor stability. Because of the inherently slow response of biological systems, the effect of changes to operating conditions can go undetected for long periods of time. To successfully demonstrate steady-state, continuous denitrification operating parameters such as temperature, $\mathrm{pH}$, and residence time, substrate concentrations must be maintained at constant levels for extended periods. The Phase I tests will focus on the demonstration and operation of the pilot-scale biodenitrification system for extended process times, with occasional minor modifications to the operating conditions. These experiments will be conducted to determine the operating range of the process.

The data acquisition system (DAS) will be used to record temperature and $\mathrm{pH}$ levels at 30 -min intervals. In addition to temperature and $\mathrm{pH}$ measurements, the reactor contents will be sampled periodically to determine biomass, nitrate, acetate, and total organic carbon (TOC) or COD concentrations. Sampling ports are also incorporated at various locations in the piping between equipment for diagnostic purposes. Biomass concentrations will be measured as volatile suspended solids using standard analytical methods. Nitrate levels will be determined spectrophotometrically using a standard cadmium reduction method, and periodically confirmed using ion chromatography. Acetate levels will be measured using gas chromatography. An in-line off-gas analyzer will monitor $\mathrm{CO}_{2}$ concentrations from the reactor exhaust to provide real-time determination of reactor performance. Periodic samples of the feed, the reactor effluent, the clarifier effluent, and the sludge recycle streams are required for analysis of concentrations and determination of denitrification efficiencies and reaction kinetics. 


\section{FY 1988 Tests Completed}

Pilot-plant shakedown tests were conducted with water before actual operation with microorganisms to calibrate instruments, check for leaks, and test equipment operation. During the initial filling with water, the clarifier vessel failed at the slanted face along a glued seam. The clarifier was

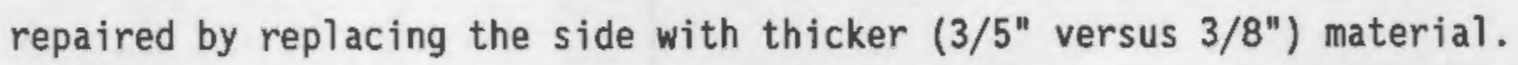
Stiffening ribs were also added. During this time, extra structural support for the feed tanks was also attached to the module framework.

The bioreactor was charged with simulated U1/U2 groundwater and $4 \mathrm{~L}$ of a microorganism culture, and then started in batch mode. When the effluent nitrate level reached $44 \mathrm{ppm}$, continuous feed to the bioreactor was initiated. After several days operation at a feed rate of 1 to $2 \mathrm{~L} / \mathrm{h}$ with no recycle, the reactor effluent nitrate concentration dropped to $4 \mathrm{ppm}$, well below the 44-ppm drinking water standard. As of this writing, the feed flow rate has been increased to $4 \mathrm{~L} / \mathrm{h}$, the clarifier is filling and recycle from the clarifier to increase the reactor biomass concentration has not yet been initiated. FY 1989 testing will bring the system to equilibrium at prototypic conditions and will determine reasonable recycle rates and other system parameters. Later tests will then demonstrate nitrate and $\mathrm{CCl}_{4}$ degradation over an extended period.

\section{Problems/Resolution}

Most of the bioreactor operational problems seen so far have been equipment related. Modifications will be needed to the feed flow control system and reactor temperature controller. The feed flow meter (a simple tube-delta pressure arrangement) has an unacceptably high noise-to-signal ratio and will be replaced with another flowmeter. A proportional temperature control system will be installed on the bioreactor to better control temperature fluctuations. In addition, the off-gas flow and $\mathrm{CO}_{2}$ monitoring equipment have yet to be tested. The off-gas flow rate and $\mathrm{CO}_{2}$ level are expected to be important process control parameters. 



\section{$\underline{U_{3}}$ PLANT CONDENSATE TESTS}

The $\mathrm{UO}_{3} \mathrm{Plant}$ process condensate contains the combined overheads streams from three uranyl nitrate (UNH) concentrators. The process condensate contains nitrate in concentrations of $10^{2}$ to $10^{4} \mathrm{ppm}$ with low levels of fluoride, uranium, and other metals. The present disposal process involves addition of phosphoric acid and neutralization to decrease the uranium soil mobility and subsequent disposal to the 216-U-17 crib. The objective of the denitrification study was to evaluate the use of biological technology for nitrate destruction in the process condensate stream.

\section{LABORATORY DENITRIFICATION RESULTS}

Three samples of the $\mathrm{UO}_{3} \mathrm{Pl}$ ant condensate were obtained during testing of a uranium treatment technology test conducted by Westinghouse Hanford Company (WHC) in February 1988. These samples were used in batch culture biodenitrification studies to determine if biodenitrification is a feasible mechanism for nitrate reduction and to determine the rate and extent of biological denitrification. Three condensates were used: condensate neutralized and treated for $U$ removal (sample no. $N-1$ ), condensate neutralized but not treated for $U$ removal (sample no. $\mathrm{N}-3$ ); and condensate unneutralized and untreated (sample no. Pre-3).

Each plant process condensate was divided into two batches. One batch was amended with inorganic and organic nutrients (i.e., acetate); the second batch did not receive nutrients. The condensates were boiled under $\mathrm{N}_{2}$ to remove $\mathrm{O}_{2}$, transferred into an anaerobic chamber, and dispensed $(10 \mathrm{~mL})$ into $20-\mathrm{mL}$ septa vials. Acetylene $(1 \mathrm{~mL})$ was injected into each vial to inhibit nitrous oxide reductase and allow for an accumulation of measurable $\mathrm{N}_{2} \mathrm{O}$. The vials were inoculated with denitrifying bacteria and incubated at room temperature. Denitrification was assayed by monitoring $\mathrm{N}_{2} \mathrm{O}$ production using a gas chromatograph equipped with an electron capture detector. Similarly treated vials without inoculation served as controls to monitor abiotic denitrification. 
Denitrification was observed in all the condensates amended with nutrients and inoculated with denitrifying bacteria (Figure 12), and was not observed in either the unamended or uninoculated samples. This observation suggests that biological denitrification of $\mathrm{UO}_{3} \mathrm{Plant}$ process condensate is feasible; however, nutrient addition will be required. Further studies are necessary to determine the optimum conditions (i.e., nutrient addition) for nitrate removal.

The extent and rate of denitrification varied between the three condensates (Table 6). Condensate $\mathrm{N}-1$ exhibited a $42 \%$ reduction in $\mathrm{NO}_{3}^{-}$while $\mathrm{N}-3$ and Pre-3 exhibited a $3.2 \%$ and $5.6 \%$ reduction in nitrate, respectively. Based on the molar concentration of organic carbon (i.e., acetate) added to each vial $\left(2.44 \times 10^{-5}\right.$ moles $)$, approximately $3.05 \times 10^{-5}$ moles of $\mathrm{NO}_{3}^{-}$should have been removed from the vials (based on 0.8 -mole organic carbon needed

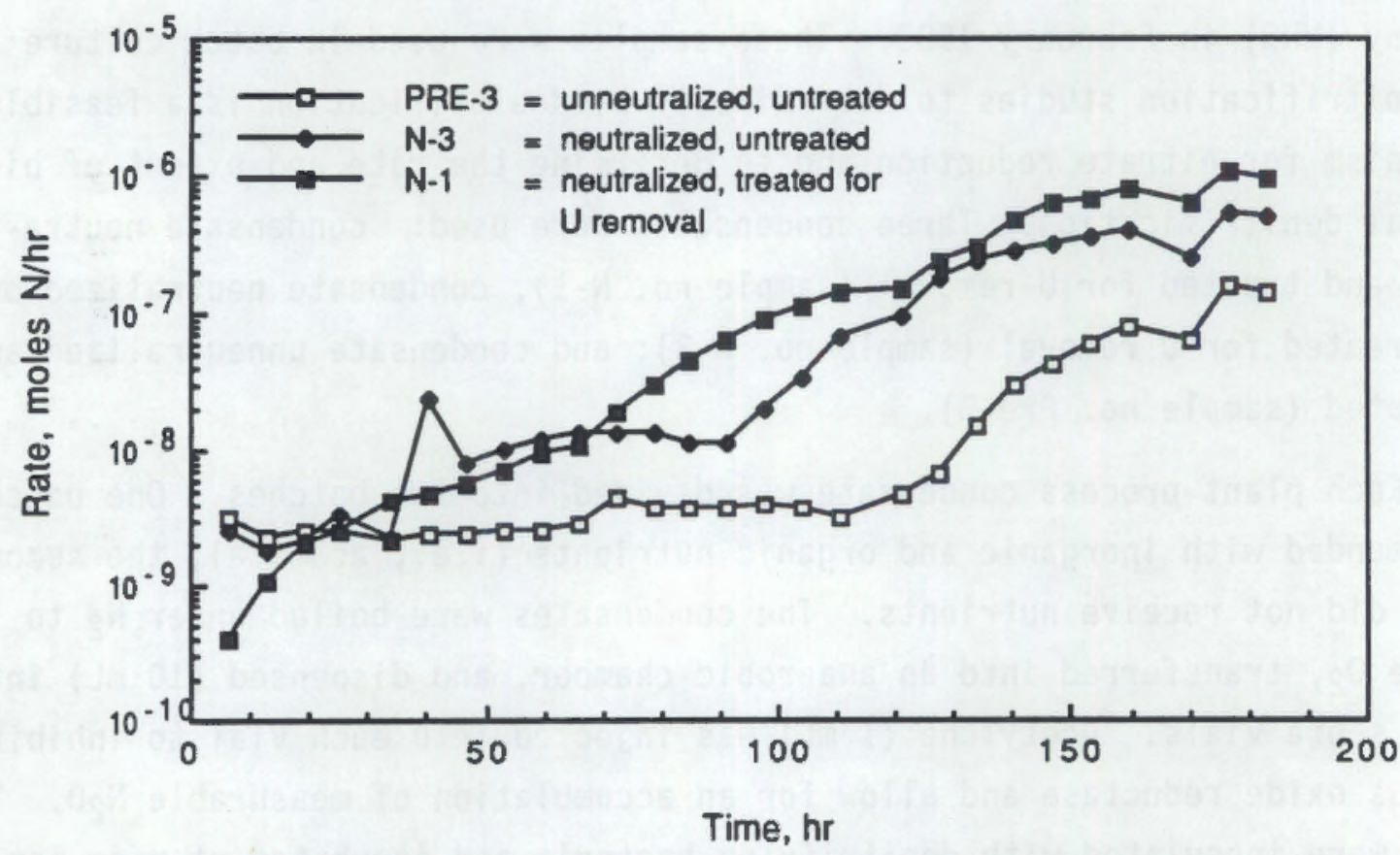

FIGURE 12. Test 1: Laboratory Denitrification Rate in Moles of Nitrogen Produced per Hour from a $10-\mathrm{mL}$ Sample 
TABLE 6. Biological Denitrification of Process Condensate for a 10-mL Sample Diluted 10:1 with Water

\begin{tabular}{|c|c|c|c|c|c|}
\hline ndensate & $\underset{\text { (moles) }}{\text { Init. }} \mathrm{NO}_{3}^{-}$ & $\begin{array}{l}\text { Final } \mathrm{NO}_{3}^{-} \\
\text {(moles) }\end{array}$ & $\begin{array}{c}\text { Consumed } \\
\mathrm{NO}_{3}^{-} \text {(moles) }\end{array}$ & $\begin{array}{l}\text { Biomass } \\
\text { Conc. }(g / \mathrm{mL})\end{array}$ & $\begin{array}{l}\text { Rate Const. } \\
\text { (g NO } \mathrm{Ner}_{3}^{\mathrm{g}} \\
\text { biomass } \cdot \mathrm{h} \text { ) }\end{array}$ \\
\hline$N-1$ & $1.31 \times 10^{-4}$ & $7.58 \times 10^{-5}$ & $5.52 \times 10^{-5}$ & $3.50 \times 10^{-4}$ & $8.50 \times 10^{-3}$ \\
\hline$N-3$ & $3.02 \times 10^{-4}$ & $2.92 \times 10^{-4}$ & $1.00 \times 10^{-5}$ & $3.50 \times 10^{-4}$ & $4.60 \times 10^{-3}$ \\
\hline Pre-3 & $2.58 \times 10^{-4}$ & $2.44 \times 10^{-4}$ & $1.40 \times 10^{-5}$ & $2.58 \times 10^{-4}$ & $2.10 \times 10^{-3}$ \\
\hline
\end{tabular}

for each mole $\mathrm{NO}_{3}^{-}$). Rate constants calculated from the denitrification data varied from $2 \times 10^{-3}$ to $9 \times 10^{-3} \mathrm{~g} \mathrm{NO}_{3}^{-}$destroyed per $\mathrm{g}$ biomass per hour. Additional tests were performed to verify the $\mathrm{N}_{2} \mathrm{O}$ test results.

A second laboratory batch culture experiment was performed to verify the denitrification rates. The results of the second experiment indicated that the denitrification rate is dependent on the biomass concentration and that the rate constant is independent of the solution type.

In the second experiment, the denitrification rate was measured by the decrease in nitrate in aqueous solution. Increased acetate concentration provided sufficient carbon source for complete denitrification and the biomass concentration of each sample was measured to give a better estimate of the denitrification rate constant. Figure 13 shows the denitrification rates in moles nitrate destroyed per hour, for waste condensate solutions $\mathrm{N}-1$ (neutralized and treated for uranium removal), N-3 (neutralized), and PRE-3 (unneutralized).

As in the previous experiment, the $\mathrm{N}-1$ solution showed a larger denitrification rate than the $\mathrm{N}-3$ and Pre-3 solutions. This is clearly shown by the $\%$ nitrate removed with time (Figure 14 ).

The denitrification rate constant was calculated from the denitrification rate (Figure 12) and the measured biomass concentrations. For low nitrate concentrations, the following expression describes the reaction kinetics (first order with respect to the biomass concentration and zero order with respect to nitrate): 


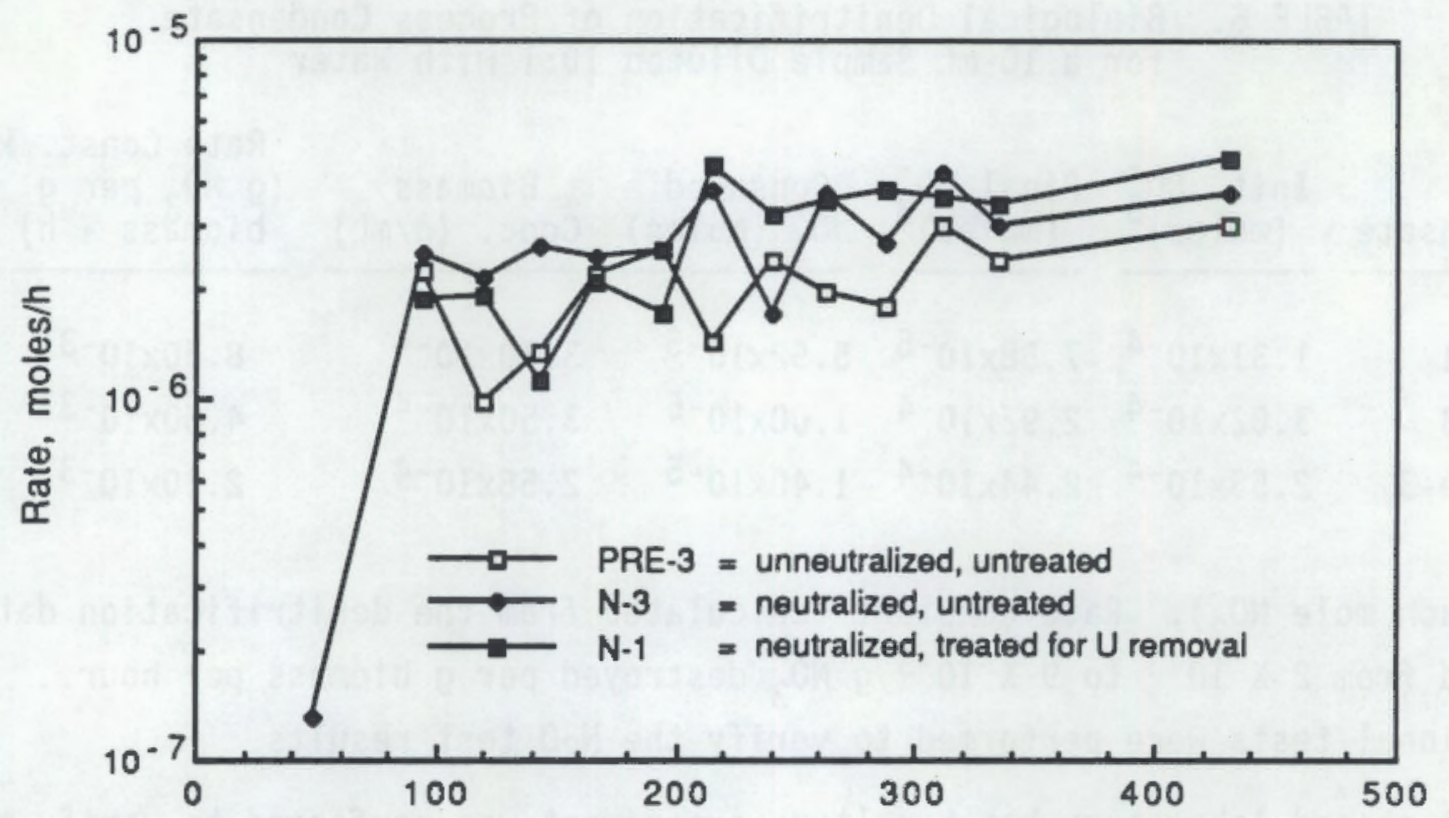

Time, $\mathrm{h}$

FIGURE 13. Test 2: Laboratory Denitrification Rates in Moles of Nitrate Destroyed per Hour from a 10-mL Sample

$-\mathrm{dS} / \mathrm{dt}=\mathrm{kX}$

where $S=$ substrate (nitrate) concentration $(\mathrm{mg} / \mathrm{L}$ )

$t=$ time $(h)$

$k=$ rate constant ( $g$ nitrate $/ g$ biomass $\cdot h$ )

$\mathrm{X}=$ biomass concentration $(\mathrm{mg} / \mathrm{L})$.

The calculated denitrification rate constant $k$ averaged $3.0 \times 10^{-3}$ to $3.3 \times 10^{-3}$ and did not vary significantly with the nitrate concentration or solution type (N-1,N-3, or PRE-3). The denitrification rate increase with time, evident in Figure 1 , is due mainly to the gradual increase in biomass concentration with time and not a change in the rate constant.

The rate constants observed during this study were about a factor of ten below those commonly reported in the literature ( $\mathrm{Cl}$ ark et a1. 1975; Sundstrom and Klei 1979), but are based on a different biomass measurement technique. 


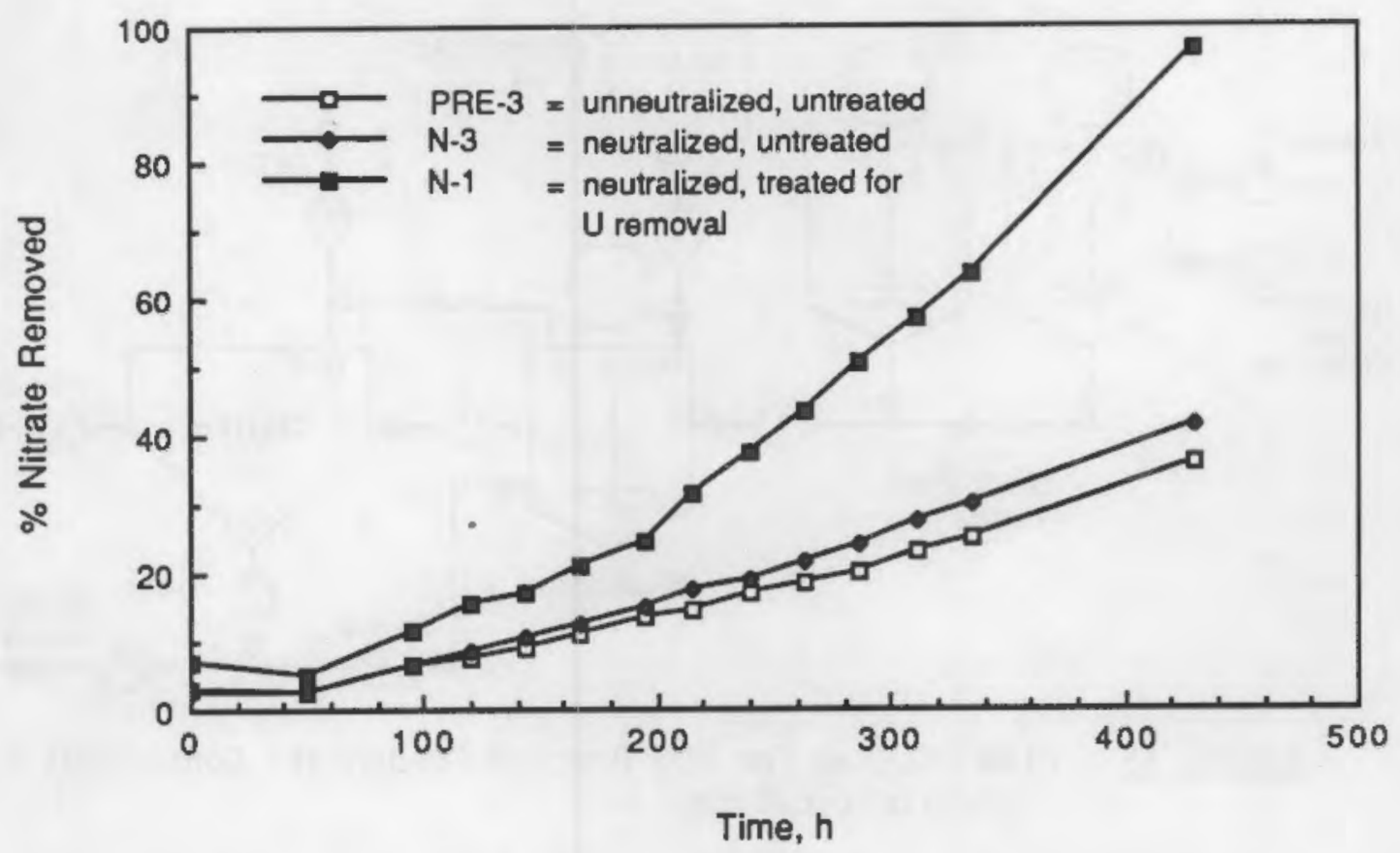

FIGURE 14. Test 2: Percent Nitrate Destroyed per Hour

PNL used a simplified technique which may have given a higher than actual estimate of biomass. In addition, groundwater denitrification rate data were not yet available when this work was conducted. Therefore, the ORNL rate constants were used ( $\mathrm{Clark}$ et al. 1975) in the flowsheet calculations instead of the measured values.

\section{BIODENITRIFICATIDN PROCESS CONCEPTUAL DESIGN}

Two flowsheets (Figures 15 and 16) were prepared and used to estimate flowrates and equipment sizes for nitrate destruction in the $\mathrm{UO}_{3} \mathrm{Plant}$ process condensate stream. Both flowsheets are based on a nitrate feed concentration of $1.6 \times 10^{4} \mathrm{ppm}$ and a process condensate flowrate of $40 \mathrm{~L} / \mathrm{min}$. The flowsheets use calcium acetate as the carbon source (substrate) and produce an effluent nitrate concentration of $30 \mathrm{ppm}$ (which is less than the drinking 


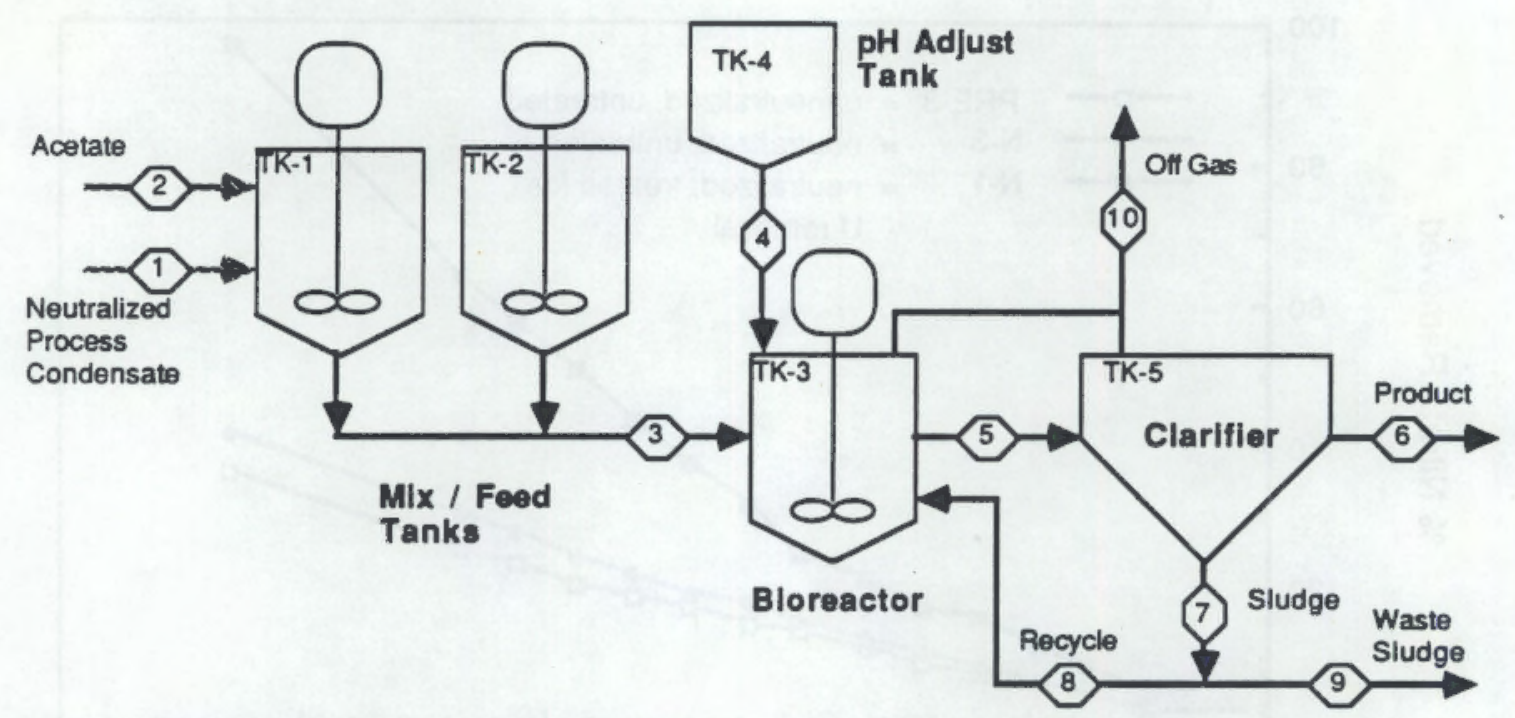

FIGURE 15. Flow Diagram for $\mathrm{UO}_{3}$ Process Condensate Continuous Biodenitrification

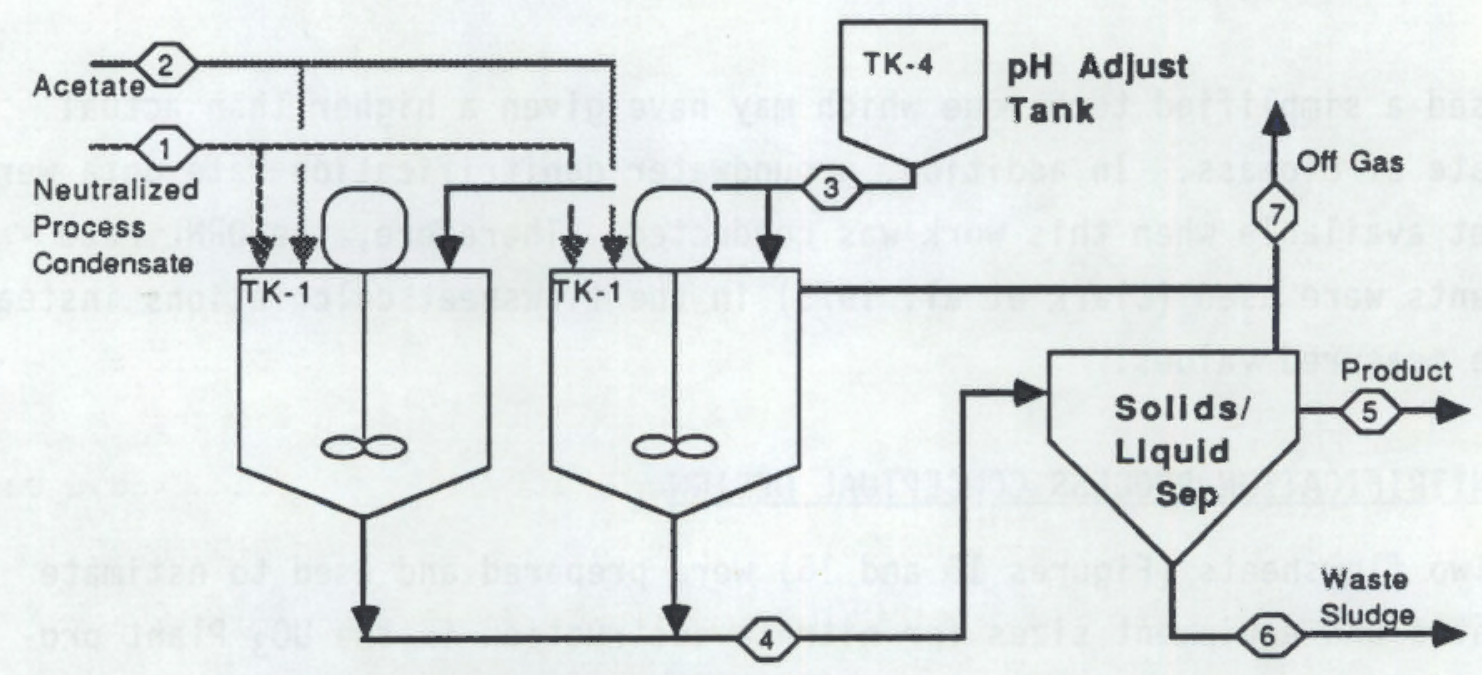

Bloreactor/Hold Tanks

FIGURE 16. Flow Diagram for $\mathrm{UO}_{3}$ Process Condensate Batch Biodenitrification

water quality standard of $42 \mathrm{ppm})$. Both processes also generate about $100 \mathrm{~kg} /$ day of biomass sludge that must be dried and disposed of as low-level solid waste. 
The conventional process (shown in Figure 15 and Table 7) uses a continuous-stirred tank bioreactor with a separate clarifier to concentrate and recycle a portion of the biomass. Other configurations are also possible, including using a filter system in place of the clarifier, or using a fluidized-bed, fixed-film bioreactor in place of the stirred-tank bioreactor and clarifier. However, too little information is presently available to make a decision on the optimum configuration.

The bioreactor for this flowsheet is a $200,000 \mathrm{~L}(55,000 \mathrm{gal})$ vessel approximately $6 \mathrm{~m}(20 \mathrm{ft})$ in diameter and $7.5 \mathrm{~m}(25 \mathrm{ft})$ tall. The clarifier, based on an expected clarified biomass concentration of $10 \mathrm{~g} / \mathrm{L}$, will be approximately $4000 \mathrm{~L}$ (1000 gal) in volume. The bioreactor size is based on ORNL published denitrification rates ( $\mathrm{Clark}$ et al. 1975) and the solids and hydrodynamic retention times calculated in the flowsheet. The proposed bioreactor is roughly twice the size of the 100,000-L 0ak Ridge Y-12 denitrification facility bioreactors (Napier 1976) which process a higher nitrate concentration ( $15 \%$ nitrate), but at a lower flowrate $(4 \mathrm{~L} / \mathrm{min})$. The Oak Ridge denitrification process produces a nitrate effluent of about $500 \mathrm{ppm}$ and does not use sludge recycle.

A second, somewhat simpler batch process is shown in Figure 16. In the batch process one of two tanks becomes a bioreactor as the other tank is filled with process condensate. The tanks are sized to permit complete denitrification in one tank while the other tank is filling. For the $40 \mathrm{~L} / \mathrm{min}$ process condensate rate, two 430,000-L (115,000-gal) tanks would be required using the same rate constants as for the conventional flowsheet (Table 8 ). This is based on an eight-day residence time, including one day for decanting and solution transfer. A $10 \%$ sludge heel is left in the tank at the end of each cycle to provide an inoculum for the next batch.

A separate solid/liquid separation device (clarifier or centrifuge) is required to further dry or dewater the biomass from either flowsheet before disposal. Determination of the settling/dewatering characteristics of the biomass sludge is beyond the scope of this study.

The advantage of the batch process is a decrease in complexity from the conventional (continuous) process. One vessel, several pumps, and at least 
TABLE 7. Flowsheet for $\mathrm{UO}_{3}$ Process Condensate Continuous Biodenitrification

\begin{tabular}{|c|c|c|c|c|c|c|c|c|c|c|}
\hline \multicolumn{11}{|l|}{ BASIS: } \\
\hline Bioreactor Temperature & $T$ & 30 & ${ }^{\circ} \mathrm{C}$ & & & & & & & \\
\hline Settled Biomass Conc. & BMC & 10 & $g / L$ & & & & & & & \\
\hline Reactor Biomass Conc. & RBMC & 3.34 & $\mathrm{~g} / \mathrm{L}$ & & & & & & & \\
\hline Rate Constant & k & 0.055 & $1 / \mathrm{h}$ & & & & & & & \\
\hline Denitration Rate & $\mathrm{rd}$ & 4.39 & \multicolumn{2}{|l|}{ g NO3/L-day } & & & & & & \\
\hline Bioreactor Working Vol & VBA & 195000 & \begin{tabular}{|l|}
$L$ \\
\end{tabular} & & & & & & & \\
\hline Nitrate Destruction Rate & NDP & 855.47 & \multicolumn{2}{|l|}{$\mathrm{kg}$ NO3/day } & & & & & & \\
\hline Nitrate Concentration & CNOB & 16 & \begin{tabular}{|l|}
$g / L$ \\
\end{tabular} & & & & & & & \\
\hline Recycle Ratio & R & 0.30 & & & & & & & & \\
\hline Hydraulic Resid. Time & Tau & 3.64 & day & & & & & & & \\
\hline Solids Detention Time & Theta & 9.12 & day & & & & & & & \\
\hline Decay Constant & $\mathrm{Kd}$ & 0.002 & \begin{tabular}{|l|} 
1/day \\
\end{tabular} & & & & & & & \\
\hline Biomass Yield Coefficient & $y$ & 0.12 & \multicolumn{2}{|c|}{ g NO3/g biomass } & & & & & & \\
\hline Effluent Nitrate Concent. & ECNOS & 0.03 & \begin{tabular}{|l|}
$g / L$ \\
\end{tabular} & & & & & & & \\
\hline & & & & & & & & & & \\
\hline & & & & & & & & & & \\
\hline & & & & & & & & & & \\
\hline Stream & 1 & 2 & 3 & 4 & 5 & 6 & 7 & 8 & 9 & 10 \\
\hline Description & Condensate & Acetate & Feed & $\mathrm{H}_{2 \mathrm{SO}}$ & Effluent & Product & Sludge & Recycle & Waste & Off Gas \\
\hline \multicolumn{11}{|l|}{ MASS FLOWS } \\
\hline Water (kg/day) & 53567 & & 53567 & 6090 & 76425.6 & 50847 & 26541 & 16471 & 10070 & 308 \\
\hline Nitrate (kg/day) & 855 & & 855 & & 2.35 & 1.54 & 0.805 & 0.500 & 0.305 & \\
\hline Calcium Acetate (kg/day) & & 681 & 681 & & & & & & & \\
\hline $\mathrm{H} 2 \mathrm{SO}_{4}(\mathrm{~kg} /$ day) & & & & 677 & & & & & & \\
\hline $\mathrm{SO} 4(\mathrm{~kg} / \mathrm{day})$ & & & & & 842 & 553 & 289 & 179 & 110 & \\
\hline Biomass (kg/day) & & & & & 268 & & 268 & 167 & 102 & \\
\hline N2 (std L/h) & & & & & & & & & & 6.06 \\
\hline $\mathrm{CO} 2$ (std Uh) & & & & & & & & & & 9.80 \\
\hline \begin{tabular}{|c|} 
\\
H2O Vapor (std L/h)
\end{tabular} & & & & & & & & & & 0.68 \\
\hline DENSITY $(\mathrm{g} / \mathrm{mL})$ & 1.000 & 0.791 & 0.997 & 1.068 & 1.000 & 1.000 & 1.010 & 1.010 & 1.010 & \\
\hline TOTAL FLOW (L/daY $\times 1000)$ & 54.42 & 0.86 & 55.25 & 6.34 & 78.23 & 51.40 & 26.83 & 16.65 & 10.18 & 0.40 \\
\hline \multicolumn{11}{|l|}{ CONCENTRATIONS } \\
\hline Nitrate $(g / L)$ & 16.00 & & 16.00 & & 0.030 & 0.030 & 0.030 & 0.030 & 0.030 & \\
\hline Calcium Acetate $(\alpha / L)$ & & 791.00 & 12.33 & & & & & & & \\
\hline $\mathrm{H} 2 \mathrm{SO}_{4}(\mathrm{~g} / \mathrm{L})$ & & & & 106.80 & & & & & & \\
\hline $\mathrm{SO} 4(\mathrm{~g} / \mathrm{L})$ & & & & & 10.77 & 10.77 & 10.77 & 10.77 & 10.77 & \\
\hline Biomass $(g / L)$ & & & & & 3.34 & & 10.00 & 10.00 & 10.00 & \\
\hline N2 (vol \%) & & & & & & & & & & 36.64 \\
\hline $\mathrm{CO} 2(\mathrm{vol} \%)$ & & & & & & & & & & 59.27 \\
\hline $\mathrm{H} 2 \mathrm{O}$ Vapor $($ vol \%) & & & & & & & & & & 4.09 \\
\hline
\end{tabular}


IABLE 8. Flowsheet for $\mathrm{UO}_{3}$ Process Condensate Batch Biodenitrification

\begin{tabular}{|c|c|c|c|c|c|c|c|}
\hline \multicolumn{8}{|l|}{ BASIS: } \\
\hline Bioreactor Temperature & $\mathrm{T}$ & 30 & ${ }^{\circ} \mathrm{C}$ & & & & \\
\hline Initial Reactor Biomass Conc. & - IRBCD & 1 & $g / L$ & & & & \\
\hline Final Aeactor Blomass Conc. & FPBC & 2.89 & $g / L$ & & & & \\
\hline Rate Constant & $\mathrm{k}$ & 1.313 & $1 /$ day & & & & \\
\hline Bioreactor Working Vol & VBR & 425797 & L/reactor & & & & \\
\hline Initial Nitrate Concentration & CNOB & 16 & $g / L$ & & & & \\
\hline Reaction Time & मTा & 6.82 & day & & & & \\
\hline Down Time & Td & 1 & day & & & & \\
\hline Decay Constant & Kd & 0.002 & $1 /$ day & & & & \\
\hline Biomass Yield Coefficient & $y$ & 0.12 & \multicolumn{2}{|c|}{$\mathrm{g} \mathrm{NO} / \mathrm{g}$ biomass } & & & \\
\hline Effluent Nitrate Concent. & ECNOS & 0.03 & $g / L$ & & & & \\
\hline & & & & & & & \\
\hline & & & & & & & \\
\hline \multirow{3}{*}{\begin{tabular}{r|} 
Stream \\
Description \\
\end{tabular}} & 1 & 2 & 3 & 4 & 5 & 6 & 7 \\
\hline & Condensate & Acetate & $\mathrm{H}_{2} \mathrm{SO}_{4}$ & Effluent & Product & Studge & Offias \\
\hline & \multicolumn{7}{|c|}{ MASS FLOWS * } \\
\hline Water $(\mathrm{kg} /$ day $)$ & 53549 & & 6199 & 60613 & 47059 & 14010 & 313 \\
\hline Nitrate (kg/day) & 871 & & & 1.85 & 1.43 & 0.42 & \\
\hline Calcium Acetate (kg/day) & & 693 & & & & & \\
\hline $\mathrm{H} 2 \mathrm{SO}_{4}(\mathrm{~kg} /$ day $)$ & & & 689 & & & & \\
\hline $\mathrm{SO} 4(\mathrm{~kg} / \mathrm{day})$ & & & & 675 & 520 & 155 & \\
\hline Biomass (kg/day) & & & & 142 & & 142 & \\
\hline N2 (std L/h) & & & & & & & 6.17 \\
\hline $\mathrm{CO} 2($ std $\mathrm{L} / \mathrm{h})$ & & & & & & & 9.98 \\
\hline H2O Vapor (std Lh) & & & & & & & 0.69 \\
\hline DENSITY $(\mathrm{g} / \mathrm{mL})$ & 1.000 & 0.791 & 1.068 & 1.000 & 1.000 & 1.010 & \\
\hline TOTAL FLOW (L/day $\times 1000)$ & 54.42 & 0.88 & 6.45 & 61.75 & 47.58 & 14.16 & 0.40 \\
\hline \multicolumn{8}{|l|}{ CONCENTRATIONS } \\
\hline Nitrate $(\mathrm{g} / \mathrm{L})$ & 16.00 & & & 0.030 & 0.030 & 0.030 & \\
\hline Calcium Acetate $(g / L)$ & & 791.00 & & & & & \\
\hline $\mathrm{H} 2 \mathrm{SO}_{4}(\mathrm{~g} / \mathrm{L})$ & & & 106.80 & & & & \\
\hline $\mathrm{SO} 4(\mathrm{~g} / \mathrm{L})$ & & & & 10.93 & 10.93 & 10.93 & \\
\hline Biomass $(g / L)$ & & & & 2.89 & & 10.00 & \\
\hline N2 ( $\mathrm{vol} \%)$ & & & & & & & 36.64 \\
\hline $\mathrm{CO} 2(\mathrm{vol} \%)$ & & & & & & & 59.27 \\
\hline \multirow[t]{2}{*}{ H2O Vapor (vol \%) } & & & & & & & 4.09 \\
\hline & & & & & & & \\
\hline \multicolumn{8}{|l|}{ - All stream flowrates are averaged } \\
\hline over an 8 day reaction cycle & & & & & & & \\
\hline
\end{tabular}


two flow control loops are eliminated from the conventional process shown in Figure 15. The disadvantage of the batch process is that two large bioreactor tanks are now required instead of one smaller tank. If existing tanks are available, the batch process would likely be a less costly alternative.

\section{COST ESTIMATE}

Although no formal cost estimates were prepared for this process, a rough order-of-magnitude cost can be obtained by comparison with other industrial water treatment processes and, where available, with other DOE installations. A cost estimate for operating an anaerobic digester with sludge recycle is $\$ 11$ per 4000 liters, when processing 400,000 L/day (DeRenzo 1978). This cost includes 10-year amortized equipment costs with a $\$ 1.3$ million capital investment. The referenced facility is larger than the $60,000 \mathrm{~L} /$ day continuous system postulated for the $\mathrm{UO}_{3} \mathrm{Pl}$ ant, but the $\mathrm{UO}_{3} \mathrm{Plant}$ biodenitrification facility would have to be constructed for processing uraniumcontaminated waste water, which would increase both the capital and operating costs over a "cold" facility.

Although no cost information is readily available for the 0ak Ridge biological processes, installation of two of the four Fernald FMPC fluidizedbed reactors reportedly cost $\$ 8$ million with another $\$ 9$ million estimated for project completion (Hopper et a1. 1987). The FMPC process is designed for a flowrate of $30 \mathrm{gpm}$ with an inlet nitrate level of about $1500 \mathrm{ppm}$. Costs for a continuous $\mathrm{UO}_{3}$ biodenitrification process would be less than for the Fernald facility because of the higher flowrate and lower nitrate feed concentrations at the FMPC. Based on this information, a rough estimate for a $\mathrm{UO}_{3} \mathrm{Plant}$ continuous denitrification facility would be between $\$ 1$ million and $\$ 5$ million. Depending upon the availability of existing tanks, the batch biodenitrification process could be implemented for considerably less than the continuous process.

Conversion of existing tanks would require installation of low-speed agitators, $\mathrm{pH}$ control, and, possibly, temperature controls for unheated 
tanks. Depending on the modifications required, the batch process could be implemented with a fraction of the capital outlay required for the continuous process.

\section{$\underline{U 0}_{3}$ STUDY CONCLUSIONS}

The major conclusions of the $\mathrm{UO}_{3}$ Plant study are that biodenitrification of the $\mathrm{UO}_{3}$ process condensate stream is feasible and further evaluation of this technology is warranted. The results of laboratory tests indicated that denitrification occurred in a11 three condensate samples tested. The app1icability of biological treatment to the $\mathrm{UO}_{3}$ process condensate stream was evaluated by preparing a preliminary flowsheet and sizing equipment. A continuous biodenitrification system using a 200,000-L bioreactor would reduce the $40 \mathrm{~L} /$ min condensate stream nitrate level to less than drinking water concentrations. Two $430,000-\mathrm{L}$ batch bioreactors would be required to achieve the same denitrification at the same inlet flow. Order of magnitude costs were also developed. For the continuous application, a capital cost of $\$ 1$ million to $\$ 5$ million was estimated. The cost to retrofit existing tanks for the batch process would be considerably less. 


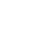




\section{REFERENCES}

Benefield, L. D., and C. W. Randall. 1980. Biological Process Design for Wastewater Treatment, p. 251. Prentice-Hall, Engelwood cliffs, New Jersey.

Bouwer, E. J., and P. L. McCarty. 1983. "Transformations of Halogenated Compounds Under Denitrifying Conditions." Appl. Environ. Microbiol. 45:12951298.

Clark, F. E., et al. 1975. Denitrification of Acid Wastes from Uranium Purification Processes. Y-1990, 0ak Ridge Y-12 Plant, Oak Ridge, Tennessee.

DeRenzo, D. J. 1978. Unit Operations for Treatment of Hazardous Industrial Wastes, pp. 225-228. Noyes Data Corp., Park Ridge, New Jersey.

Franke, H. C., F. E. Clark, and J. W. Strohecker. 1974. "Biological Denitrification Disposal Techniques." In Proceedings of the Second Annual AEC Environmenta] Conference. WASH-1332 [74], Vol. 1, pp. 339-359. Albuquerque, New Mexico, April 16-19, 1974.

Hopper, J. P., J. B. Patton, T. A. Poff, and P. A. Shanks. 1987. "Start-Up and Operation of the Biodenitrification Demonstration Facility at the FMPC." In Proceedings of the Waste Management ' 87 Conference. Tucson, Arizona, March 1987.

Knowles, R. 1982. "Denitrification." Microbiological Reviews 46(1):43-70.

McCarty, P. L., et a7. 1969. "Biological Denitrification of Wastewaters by Addition of Organic Materials." ln Proceedings of the 24th Industrial Waste Conference. Purdue University, West Lafayette, Indiana, May 1969.

Monod, J. 1949. "The Growth of Bacterial Cultures." Annual Review of Microbiology $3: 371$.

Napier, J. M. 1976. An Operational Guide to the Y-12 Denitrification Facility. Y-DA-6720, Oak Ridge Y-12 Plant, Oak Ridge, Tennessee.

Sundstrom, D. W. and H. E. Klei. 1979. Waste Water Treatment, pp. 163-164. Prentice-Hall, Engelwood Cliffs, New Jersey.

Sutton, P. M. 1987. "Biological Treatment of Surface and Groundwater." Pollution Engineering, July 1987.

Walker, J. F., et al. 1981. "Biological Treatment of Nitrate Waste Water Using Fluidized-Bed Bioreactors." In Biotechnology and Bioengineering Symposium No. 11, pp. 415-427. John Wiley and Sons, Inc.

Walker, J. F., M. V. Helfrich and T. L. Donaldson. 1987. The Biodenitrification Program. ORNL/TM-10239, Oak Ridge National Laboratory, Oak Ridge, Tennessee. 



\section{DISTRIBUTION}

No. of

Copies

\section{OFFSITE}

10 DOE/Office of Scientific and Technical Information

7 R. Archer

Martin-Marietta Energy Systems HAZWRAP

P.0. Box 2003

Building K-1210

0ak Ridge, TN 37831-7256

J. W. Blackburn

5724 Outer Drive

Knoxville, TN 37921

J. Daniels

Lawrence Livermore National Laboratory

P.0. Box 808

Livermore, CA 94550

W. Hansen

Los Alamos National Laboratory

P.0. Box 1663

MS F643

Los Alamos, NM 87545

T. C. Hazen

Savannah River Laboratory

Building 773-42A

Aiken, SC 29808

J. E. Helt

Argonne National Laboratory

9700 South Cass Avenue

Argonne, IL 60439

G. Hendrey

Brookhaven National Laboratory

Environmental Biotechnology

Division

Upton, NY 11973

L. Johnson

EG\&G Idaho

P.0. Box 1625

Idaho Falls, I0 83415
No. of

Copies

T. Michelena

Washington Department of Ecology

MS PV-11

0lympia, WA 98504

3 Oak Ridge National Laboratory

P.0. BoX 200B

Oak Ridge, TN 37830

ATTN: T. Donaldson

C. Gehrs

P. T. Owen

\section{ONSITE}

7 DOE Richland Operations Office

J. J. Broderick

P. K. Clark

J. D. Goodenough

S. Prestwick

G. W. Rosenwald

W. B. Schulze

R. K. Stewart

7 Westinghouse Hanford Company

J. W. Cammann

D. L. Flyckt

D. C. Hedengren

W. F. Heine

K. M. Hodgson

A. P. Larrick

J. P. Sloughter

21 Pacific Northwest Laboratory

W. F. Bonner

T. M. Brouns

T. L. Brown

J. L. Buelt

W. 0 . Heath

R. J. Hicks

S. S. Koegler (5)

J. L. McEIroy

T. J. McLaughl in

T. L. Stewart

J. L. Straal sund

Publishing Coordination

Technical Report Files (5) 
